\title{
Kuşak Yol Girişimi Kapsamında Deniz ve Demir Ípekyolu'nun Rekabeti
}

\section{Competition of Maritime and Iron Silk Road within the Scope of Belt and Road Initiative}

\author{
Baha Emir ŞAHIN ${ }^{\star}$ - Fahri ERENEL ${ }^{\star \star}$
}

$\ddot{O} z$

Kuşak Yol Projesi kapsaminda Çin'den yola çıkan ve Türkiye'den geçerek Avrupa'ya ulaşan ilk tren ile birlikte, Demir İpekyolu'nun Türkiye'ye ve deniz taşımactlı̆̆nna etkisi ile ilgili tartışmalar artmıştır. Bu noktadan yola çıkan çalısma, Demir İpekyolu'nun konteyner taşımacllğ̆ üzerinden Deniz İpekyolu ile güncel kapasitelerini ve gelecekte beklenen kapasitelerini karşılaştrmayn amaçlamaktadır. Çalışma, ayn zamanda Kuşak Yol Projesi kapsaminda güncel olarak kullanilan veya gelecekte kullanılması beklenen denizyolu ve demiryolu güzergâhlar, bu güzergâhlardaki darboğazlar ve taşımacıllk açısından yaşanan zorluklar da özetlemeyi hedeflemektedir. Bununla beraber Çin'in özellikle deniz darboğazlarn çevresindeki askerî ve ekonomik tutumu da incelenecektir.

Anahtar Kelimeler: Kuşak Yol, Deniz İpekyolu, Demir İpekyolu, Konteyner Taşımacıllğ̆, Kuşak Yol Güzergâhları.

\section{Abstract}

The Belt and Road Initiative, with the first train reaching Europe from China by passing through Turkey, has increased debate about the effects of the Iron Silk Road and sea transport on Turkey. Setting out from this point, this study aims to compare the current capacities of Iron Silk Road with Maritime Silk Road through container transportation and its expected capacity in the future. This study also aims to summarize the sea and rail routes that are currently used or expected to be used in the scope of the Belt and Road Initiative, the narrow passes on these routes and the difficulties experienced in terms of

* Yüksek Lisans Öğrencisi, Millî Savunma Üniversitesi, Atatürk Stratejik Araştırmalar Enstitüsü, İstanbul, Türkiye, ORCID: 0000-0003-4944-4043, e-posta: baha.emir.sahin@gmail.com.

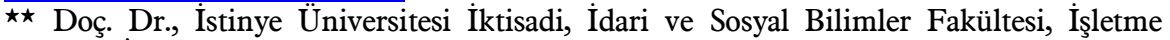
Bölümü, İstanbul, Türkiye, ORCID: 0000-0001-8943-7265, e-posta: ferenel@istinye.edu.tr.

Geliş Tarihi / Submitted: 12.07.2020

Kabul Tarihi / Accepted: 20.11.2020 
transportation. In addition, China's military and economic attitude, especially around the narrow passes of sea, will also be examined.

Keywords: Belt and Road, Maritime Silk Road, Iron Silk Road, Container Transportation, Belt and Road Routes.

\section{Giriş}

Ulaşım yolları tarihsel süreç içerisinde gelişen araçlar vasıtasıyla insanlar ve toplumlar arasındaki mekân ilişkisini sağlayan en önemli unsur olmuştur. Tarihin en eski zamanlarından bu yana çok çeşitli ulaşım yolları toplumlar ve devletler arasındaki mekân ilişkisinin gerçekleşmesini sağlamıştır. Ancak her ulaşım yolu zamanı aşıp günümüze kadar adını duyuramamış, zamanla yok olup gitmiştir. Ulaşım yolunu değerli ve kalıcı kılan etken bulunduğu jeopolitik ve jeostratejik konumuna, toplumların sosyal ve iktisadi ilişkilerini güvenli şekilde gerçekleştirmesini sağlamasına bağlıdır. Bu bağlamda insanlık tarihinin en eski ve değerli ulaşım yolu Avrupa'dan Asya'ya Asya'dan Afrika'ya kadar büyük bir coğrafyayı kapsayan, birçok kadim medeniyetin doğduğu İpek Yolu'dur. Özbeklere ait olan "Kâinatta iki büyük yol vardır; gökyüzünde Samanyolu yeryüzünde İpek Yolu" atasözü birçok ulus için İpek Yolu'nun önemli olduğunu kanıtlar niteliktedir. İpek Yolu güzergâhı üzerinde yer alan ülkeler arasında ticaret başta olmak üzere siyasal, kültürel ilişkilerin gelişmesinde ve toplumların etkileşiminde önemli rol oynamıştır. Geçmişi 4000 yıl öncesine dayanan tarihî İpek Yolu günümüzde de uluslararası nitelikte önemini korumaktadır. ${ }^{1}$

İpek Yolu ismini literatüre kazandıran isim Alman F. Von Richthofen 1877 yılında yazdığı Çin adlı eserinde Çin'den batı ülkelerine gönderilen ipeğin bu yoldan nakliye edilmesinden bahsetmektedir. ${ }^{2}$

Tamamı Avrasya topraklarında olmak üzere karasal teorilerin geliştirilmesinde göz önünde bulundurulan kara yollarının başında, Jiangsu'dan başlayıp bütün bir kıtayı geçerek Roma'ya ulaşan $11.000 \mathrm{~km}$ uzunluğundaki İpek Yolu (Silk Road) gelir. Aynı zaman dilimi içinde İpek

\footnotetext{
${ }^{1}$ Filiz Kutluay Tutar ve Fatma Şura Bahsi Koçer, "Çin'in Yeni İpek Yolu Projesi: Bir Kuşak Bir Yol”, Fournal Of Social, Humanities and Administrative Sciences, 2019, Vol. 5, No. 17, 618-626, s. 619.

${ }^{2}$ Filiz Kutluay Tutar ve Fatma Şura Bahsi Koçer, a.g.e., s. 619.
} 
Yolu kadar önemli ve uzun olmasa da Avrupa'da ticari açıdan iki önemli yol daha bulunmaktaydi; bunlardan Kehribar Yolu (Amber Road) Baltık Denizi'nden başlayıp, tüm Avrupa kıtasını kuzeyden güneye geçerek Venedik'ten Roma'ya ulaşırdı. Daha kısa olan birkaç şarap yolu içinde en önemlisi olan Şarap Yolu (Vine Road) ise; bugünkü Kuzey Makedonya'daki Vardar Vadisi'nden başlar, Selanik Limanı'na yük olarak ulaşır, bir diğer önemli şarap yolu da Alsace bölgesindeki Strasbourg'dan başlar, bugünkü Almanya-Fransa-İsviçre sınırlarının kesiştiği Mulhouse'da son bulurdu. Zenginliğin kaynağını oluşturan bu ticaretlerin devamlı olabilmesi için de yolların açık ve güvenliğinin sağlanmış olması gerekirdi. ${ }^{3}$

\section{Bir Kuşak Bir Yol Projesi’nin Ortaya Çıkışı ve Gelişimi}

Çin'in Han Hanedanı döneminde teşkil edilen İpekyolu'ndan alınan ilham ile oluşturulmuş Kuşak Yol projesinden, Çin Halk Cumhuriyeti Başkanı Xi Jinping, resmî olarak ilk defa Kazakistan'a yaptığ ziyaretinde bahsetmiştir. ${ }^{4}$

07 Eylül 2013 tarihinde, Kazakistan Nazarbayev Üniversitesi'nde "İnsan-İnsan Dostluğunu Geliştir ve Daha İyi Bir Gelecek Yarat” başlıklı konuşmasında Jinping, “Avrasya ülkeleri arasındaki ekonomik bağları güçlendirmek, karşılıklı iş birliğini derinleştirerek gelişme alanlarını çoğaltmak için iş birliği yöntemlerinin yenilenebileceği ve adım adım ortaklaşa "İpek Yolu Ekonomik Kuşağı"nı birlikte inşa etmeyi önererek bölgesel iş birliği için; siyasal iletişimi güçlendirmek, karayolu bağlantısını geliştirerek Pasifik'ten Baltık Denizi'ne ulaşım kanalını açmak ve giderek Doğu Asya, Batı Asya ve Güney Asya'yı birbirine bağlayan bir ulaşım ağı oluşturmak, finansal serbestliğin sağlanabilmesi ve paranın dolaşım hızının artırılabilmesi için yerel para birimlerinin birbirleri ile takas edilmesini kolaylaştırmak ve insandan insana ticareti geliştirmek için dostluğu teşvik

\footnotetext{
3 “Yeni Dünya Düzeni'nin Kurulus Projesi-Yeni İpek Yolu”, 21. Yüzynl Türkiye Enstitüsü, 22.12.2020, https://www.21yyte.org/tr/merkezler/bolgesel-arastirma-merkezleri/asya-pasifik -arastirmalari-merkezi/yeni-dunya-duzeninin-kurulus-projesi-kusak-ve-yol-girisimiyeni-i-pek-yolu_(Erişim Tarihi: 23.12.2020).

4 "President Xi Jinping Delivers Important Speech and Proposes to Build a Silk Road Economic Belt with Central Asian Countries", Ministary of Foreign Affairs of The People's Republic of China, https://www.fmprc.gov.cn/mfa_eng/topics_665678/xjpfwzy siesgjtfhshzzfh_665686/t1076334.shtml (Erişim Tarihi: 01.17.2020).
} 
etmek, gerektiğini ifade etmiştir. Bu konuşmadan kısa bir süre sonra, Endonezya'da yaptığı konuşma ile bu kez deniz yollarının birbirlerine bağlanması ile ilgili düşüncelerini açıkladı Jinping. Bu konuşmaya göre proje, kara ve deniz yollarının birbirine bağlandığı küresel ölçekte ticareti kontrol etmeyi amaçlayan bir proje kapsamında idi. ${ }^{5}$

Başlangıçta, eski İpek Yolu'nun canlandırılarak Asya ile Avrupa'yı birbirine bağlamak amacıyla geliştirildiği ilan edilen proje, yıllar içinde genişleyerek kapsamına yeni toprakları ve yeni kalkınma girişimlerini dâhil etmiştir. Çinli yetkililerin "Yüzyılın Projesi" olarak isimlendirdiği proje, 69 üye ülkeyi, dünya nüfusunun \%65'ini, dünya Gayrisafi Yurtiçi Hasıla'sının \%42'sini, bilinen enerji rezervlerinin \%75'ini, dünya kara yüzölçümünün \%40 kadarını kapsamaktadır. Çin, altyapı yatırımlarını 30-35 yılda tamamlayarak, Çin Halk Cumhuriyeti'nin kuruluşunun 100. y1lı olan 2049'da, bu girişime tüm yönleriyle işlerlik kazandırmayı planlamaktadır. Bu sürede karayolları, demiryolları, limanlar, güç şebekeleri, doğal gaz boru hatları ve altyapı projeleri tamamlanacak, bankacılık işlemleri, ortak mevzuat, güvenlik ve iş birliği anlaşmaları ve politik birliktelikler yoluyla malların paranın ve insanların serbest dolaşımı sağlanmış olacaktır. ${ }^{6}$

Proje'nin içine dâhil edilebileceği teorik çerçeveyi anlayabilmek için dünya egemenliğini açıklamaya çalışan klasik uluslararası ilişkiler teorilerini göz önünde bulundurmak zorunludur. İki ana teoriden biri olan ve karasal hâkimiyeti öne çıkaran teoriye göre, dünya egemenliği, ana karayolları ve önemli coğrafyaların kontrol edilmesi ile mümkün olabilir. Bir diğer teoriye göre ise, ana ticaret akımlarının üzerinde yer alan denizlere hâkim olmak, dünya hâkimiyetinin ele geçirilmesi açısından zorunludur. ${ }^{7}$

\footnotetext{
5 “Yeni Dünya Düzeni'nin Kuruluş Projesi-Yeni İpek Yolu”, 21. Yüzynl Türkiye Enstitüsü, 22.12.2020, https://www.21yyte.org/tr/merkezler/bolgesel-arastirma-merkezleri/asya-pasifik -arastirmalari-merkezi/yeni-dunya-duzeninin-kurulus-projesi-kusak-ve-yol-girisimiyeni-i-pek-yolu_(Erişim Tarihi: 23.12.2020).

6 "Yeni Dünya Düzeni’nin Kuruluş Projesi-Yeni İpek Yolu”, 21. Yüzynl Türkiye Enstitüsü, 22.12.2020, https://www.21yyte.org/tr/merkezler/bolgesel-arastirma-merkezleri/asya-pasifik -arastirmalari-merkezi/yeni-dunya-duzeninin-kurulus-projesi-kusak-ve-yol-girisimi-yeni-ipek-yolu_(Erişim Tarihi: 23.12.2020).

7 "Yeni Dünya Düzeni'nin Kuruluş Projesi-Yeni İpek Yolu”, 21. Yüzyıl Türkiye Enstitüsü, 22.12.2020, https://www.21yyte.org/tr/merkezler/bolgesel-arastirma-merkez leri/asya-pasifik-arastirmalari-merkezi/yeni-dunya-duzeninin-kurulus-projesi-kusakve-yol-girisimi-yeni-i-pek-yolu_(Erişim Tarihi: 23.12.2020).
} 
Tarihî İpek Yolu'nu yeniden canlandırmayı amaçlayan Kuşak ve Yol girişimi iki büyük hattan oluşmaktadır. Kara hattı olarak UrumçiTahran-İstanbul hattını izleyen "İpek Yolu Ekonomik Kuşağı" ve denizde Gwadar-Kenya-Cibuti-Pire hattını izleyen "21. Yüzyılda Deniz İpek Yolu". Bunun dışında yine bu hatlara bağlanan stratejik koridorlar söz konusudur. Hatta kendisini "kuzey kutbuna yakın devlet" olarak tanımlayan Çin, "kutup ipek yolundan” da bahsetmektedir. Böylece Avrupa'ya yapılan ticarette nakliye süresini kısaltmanın hesaplarını yapan Pekin aynı zamanda Çin-Pakistan ekonomik koridoru ile Malakka boğazına olan bağımlılı̆̆ını azaltmaya çalışmaktadır. ${ }^{8}$

Kuşak Yol projesi Çin'in dış politikada sürdürmüş olduğu pro-aktif dış politika yaklaşımının bir yansıması olarak kabul edilmelidir. Bu proje ile Çin, iktisadi gücü ile küresel bir etki oluşturmak, uluslararası sistemde daha etkin olmak ve güçlü, büyük ülke imajını korumak istemektedir. ${ }^{9}$

\section{Araştırmanın Önemi}

2019 yılında Çin'den gelen ve ülkemiz üzerinden transit geçerek Prag'a giden ilk yük treni ile beraber, Kuşak Yol Projesi Türkiye için bir proje olmaktan çıkıp gerçeklik haline dönüşmüştür.

Bu süreçte, Çin'in Kuşak Yol atılımının altında yatan; ekonomik hedefleri, finanse ettiği veya satın aldığı altyapı çalışmaları gibi alt başlıkları inceleyen birçok çalışma yapılmış olsa da; projenin isminde yer alan Kuşak yani Çin'i Orta Asya üzerinden Avrupa'ya bağlayan demiryolları ile Yol'un, yani Çin'den Avrupa'ya uzanan deniz rotaları üzerinde yapılan taşımaların hacmini kıyaslayan ve mukayese eden çalışmaların literatür taraması sonucunda yeterli olmadığı değerlendirilmiştir.

Özellikle; Türkiye'yi Demir İpekyolu'na bağlayan Bakü-Tiflis-Kars hattının açılmasıyla birlikte, konuya artan ilgi de dikkate alınarak, Avrasya ticareti açısından Demir İpekyolu ile Deniz İpekyolu arasındaki rekabet bu makale ile araştırılmaya çalışılmıştır.

\footnotetext{
8 "Kuşak ve Yol Girişiminin Geleceği: Çin Karakterli Bir küreselleşme mi?", Anadolu Ajansı, 21.12.2020, https://www.aa.com.tr/tr/analiz/kusak-ve-yol-girisiminin-gelecegicin-karakterli-bir-kuresellesme-mi/2083696 (Erişim Tarihi: 23.12.2020).

${ }^{9}$ Filiz Kutluay Tutar ve Fatma Şura Bahsi Koçer, a.g.e., s. 619.
} 
İncelemenin merkezine, yapılan ticaretin bir özeti niteliğinde olması nedeniyle, Avrasya hatlarında yapılan konteyner taşımalarını alacak olan çalışma; Demir İpekyolu'nun, Deniz İpekyolu'na göre taşımacılıktaki payını belirlemeyi hedeflemektedir. Demir Ípekyolu'nun kapasite açısından Deniz İpekyolu'na ikame olup olmadığını belirleyebilmek ise araştırmanın önemini ortaya koymaktadir.

\section{Araştırma Tasarımı}

İncelemeye öncelikle; Deniz İpekyolu'ndaki deniz darboğazları, bu darboğazların çevresinde Çin'in ekonomik-askerî politikası ve Kuzey Deniz Rotası özetlenerek başlanacaktır. Müteakiben, Demir Ípekyolu; Avrasya ticareti açısından, taşımacıllk güzergâhları ve taşımalarda yaşanan teknik zorluklar üzerinden incelenecektir. Son olarak arşiv araştırması neticesinde elde edilen veriler incelenerek gerekli karşılaştırmanın yapılacağı sonuç bölümüne geçilecek ve Demir İpekyolu için SWOT analizi yapılacaktır.

Güzergâhların, taşıma modu kapasitelerinin, darboğazların, güvenlik faaliyetlerinin ve coğrafyanın özetlenmesinde, şekillerden yoğun olarak yararlanılarak, jeo-lojistik bir anlatım dili yakalamak hedeflenmektedir.

Araştırma; "Demiryolu, denizyoluna; Avrasya'da yapılan ticari taşımalar için kapasite açısından ikame olabilir mi?" araştırma sorusu çevresinde şekillenecektir. Aynı zamanda; “Gelecekte Avrasya'da yapılan ticari taşımalar için; demiryolu, denizyoluna kapasite açısından ikame olabilir mi?”, “Avrasya ticaretinde demiryolu ile yapılan taşımaların payı nedir?" ve "Demiryolunun diğer taşıma modlarına göre üstün yönleri nelerdir?" soruları, çalışmanın cevaplamayı hedeflediği alt sorulardır.

Araştırmada, Avrasya'da yapılan ticari taşımalar evren olarak kabul etmiştir. Tarihî İpek Yolu üzerindeki stratejik güç mücadelesi günümüzde de devam etmektedir. İlk bakışta coğrafi birer kavram gibi duran jeopolitik, jeoekonomik ve jeostratejik bağlamda ortaklığı bulunan İpek Yolu ve Avrasya gibi kapsamı oldukça geniş iki önemli kavramı birbirinden bağımsız düşünmek mümkün değildir. Sosyal bilimlerin çeşitli disiplinlerinde 20. yüzyıldan itibaren kullanılmaya başlanan Avrasya kavramı ile tarihî kökenleri çok eski olan İpek Yolu uluslararası ekonomi-politik sistemin önemli dinamik aktarım hattını oluşturmaktadır. Bu bağlamda Avrasya bölgesindeki kaynakların Tarihî İpek Yolu dönemindeki gibi yeniden rasyonel kullanımını sağlamak ve bölgenin uluslararası sistemdeki stratejik 
gücünü artırmak için ekonomi-politik bir yapılanma kaçınılmaz olmuştur. Çin'in Bir Kuşak Bir Yol projesi ile İpek Yolu'nu yeniden canlandırma girişimi bu düşünceyle örtüşmektedir. ${ }^{10}$

Yapılan ticari taşımaların bir özeti niteliğinde olması sebebiyle de, Avrasya'da yapılan konteyner taşımacılığı örneklem olarak belirlenmiştir. Avrasya tanımı araştırma zemininde Asya ve Avrupa kıtalarını temsil eden bir coğrafi bölge olarak kabul edilmiş ve bu coğrafi bölgede doğu batı aksında yapılan taşımalar incelemeye alınmıştır.

Nitel araştırma yöntemlerinin kullanıldığı araştırmada, arşiv taraması ile elde edilen ikincil veriler kullanılarak araştırma sorusuna cevap verilmeye çalışılacaktır. Bu ikincil veriler, UNCTAD'ın, UIC'nin ve Eurasian Development Bank'in konteyner taşımacılığı için paylaştığı veriler ve gelecek tahminleri üzerinden sağlanmış, ayrıca Demir İpekyolu'nun önemini, avantajlarını ve güncel Avrasya ticaretindeki hacmini araştıran makalelerden faydalanılmıştır.

\section{Deniz İpekyolu Rotaları ve Deniz Darboğazları}

$\mathrm{Bu}$ bölümde Kuşak Yol'un Deniz İpekyolu üzerinde bulunan coğrafi deniz darboğazları belirlenecek ve bu darboğazları aşmak veya güvenliğini sağlamak için Çin'in hamleleri üzerine genel bir resim çizilmeye çalışılacaktır. Çin'in Kuşak Yol Projesiyle yaptığı genel yatırımların tasviri yerine Yol boyunca mevcut darboğazlar çevresindeki tutumu ve Kuzey Deniz Rotası'nın önemi özetlenmeye çalışılacaktır.

Kuşak Yol ismi içinde yer alan Yol; Çin'den Doğu Afrika bağlantılı olarak, Süveyş Kanalı üzerinden, Avrupa'ya giden deniz rotasını ifade etmektedir. ${ }^{11}$ Güney Çin Deniz'inden çıkan yol; Hint Okyanusu'ndan geçmekte ve denizcilik açısından dünyanın sekiz darboğazından ikisini kullanmaktadır. Darboğaz; deniz trafiğinin bir stratejik su yolunda aşırı yoğunlaşması olarak tanımlanmaktadır ve Yol üzerindeki üç darboğaz Süveyş Kanalı ile Babülmendep ve Malakka Boğazlarıdır. ${ }^{12}$

\footnotetext{
${ }^{10}$ Filiz Kutluay Tutar ve Fatma Şura Bahsi Koçer, a.g.e., s. 620.

${ }^{11}$ Belt And Road Economics Opportunities and Risks of Transport Corridors, The World Bank Group, Washington, 2019, s. 3.

${ }^{12}$ Alba Lulia Catrinel Popescu, "Control of Key Maritime Straits - China's Global Strategic Objective", International Fournal of Economics and Business Administration,
} 
Şekil 1: Yol'un Rotaları. ${ }^{13}$

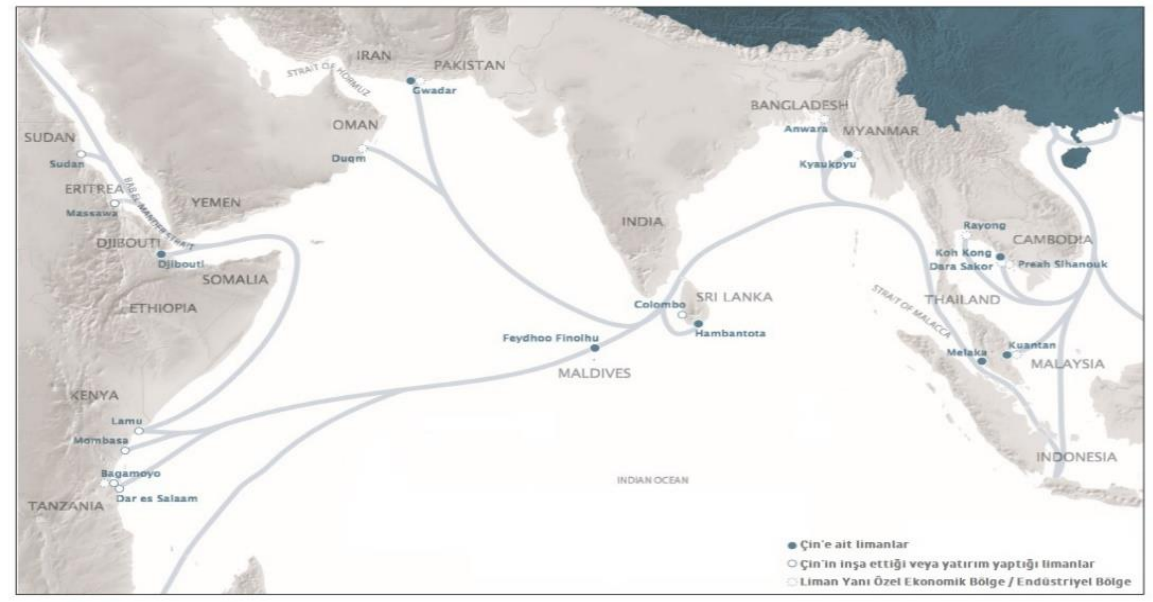

\subsection{Süveyş Kanalı ve Babülmendep Boğazı}

Hint Okyanusu'nda, Çin'in dünyanın geri kalanıyla hayat bağı olan denizyolları iki rotaya ayrılmaktadır. Bunlardan ilki Hint Okyanusu'nun kuzeyine yönelerek Hürmüz Boğazı'na çıkar. Çin'in ithal ettiği petrolün yaklaşı \% $\%$ ' 1 bu hattan gelmektedir. İkinci rota ise Babülmendep Boğazı ile Kızıldeniz'e, buradan da Süveyş Kanalı ile Akdeniz'e geçerek Avrupa pazarlarına ulaşımı sağlamaktadır. ${ }^{14}$

Süveyş Kanalı 1869 yılında Sultan Abdülaziz Han tahtta iken Osmanlı idaresindeki Mısır'da açılmıştır. İlk açıldığında; 164 km uzunluğa ve 8 metre derinliğe sahip olan kanal, 2015 yılında yapılan son düzenleme ile birlikte, $193 \mathrm{~km}$ uzunluğa ve 24 metre derinliğe erişerek dünyadaki tüm konteyner gemilerinin geçişine elverişli hale getirilmiştir. ${ }^{15} 2019$ yılında kanaldan

2017, Vol 5, No. 1, 92-119, s. 94.

${ }^{13}$ Richard Ghiasy, SU Fei vd, "The 21st Century Maritime Silk Road Security Implications and Ways Forward For The European Union", SIPRI, Stockholm, 2018, s. 28.

${ }^{14}$ Peter A. Dutton, Isaac B. Kardon, Conor M. Kennedy, "China Maritime Report No. 6: Djibouti: China's First Overseas China Maritime Report No. 6: Djibouti: China's First Overseas Strategic Strongpoint”, U.S Naval War College, Newport, 2020, s. 3.

15 “Canal Characteristics”, Suez Canal Authority, https:/www.suezcanal.gov.eg/English/ About/SuezCanal/Pages/CanalCharacteristics.aspx (Erişim Tarihi: 03.07.2020). 
günde yaklaşık 52 gemi ve yıllık toplam 18.800 gemi geçmiştir. Geçen gemilerin taşıdığı yük toplam 1.2 milyar tona denk gelmektedir ve kanaldan geçen toplam yükün yarısından fazlası konteyner gemileriyle taşınmıştır. ${ }^{16}$

Hint Okyanusu'ndan Akdeniz'e geçmek için tek alternatifi Ümit Burnu'nu dolanarak Cebelitarık Boğazı'nı geçmek olan Süveyş Kanalı'ndan dünya kargo trafiğinin yaklaşık \%8' i geçmektedir. ${ }^{17}$ Süveyş Kanalı kullanımı, Ümit Burnu rotasına göre; Singapur'dan New York'a giden bir geminin yolculuk mesafesini \%19, Basra Körfezi'nden Rotterdam'a giden bir geminin yolculuk mesafesini ise \%42 kısaltmaktadır. Süveyş Kanalı'nın 2015 yılında biten genişletme çalışmaları da Çin ile yapılan anlaşmalar doğrultusunda planlanan ve bitirilen projelerden birisidir. ${ }^{18}$

Kanal etrafında oluşan yoğun gemi trafiği korsanların da ilgisini çekmiş ve Aden Körfezi'nde; 2010 yılında 445, 2011 y1lında 439 adet korsanlık vakası meydana gelmiştir. 2014 yılına gelindiğinde ise bu rakam 3'e düşmüştür. Somali'nin otorite boşluğuyla beraber yükselen vakalar, gemi bünyesinde alınan tedbirler ve donanmaların bölgedeki aktif varlığı ile sona erme seviyesine gerilemiştir. ${ }^{19}$

2008 yılında Çin Donanması'na ait 3 gemi, ilk kez, Somali'deki korsanlığı önleme faaliyetlerine katılmıştır. Bu görev ile Çin Donanması, yüzyıllar sonra ilk defa Asya Pasifik Bölgesi'nin dışında, uzak denizlerde operasyonel olarak faaliyet yürütmüştür. Çin Dişişleri Bakanlığı Sözcüsü, Çin'in ekonomik faaliyetlerinin tehlike altına girdiğini ve Çin'in hamlesinin bu üzücü durumu düzeltmeye yönelik olduğunu belirtmiştir. ${ }^{20}$

\footnotetext{
${ }^{16}$ Suez Canal Traffic Statistics Annual Report 2019, Suez Canal Authority, Ismailia, 2020, s. 1-8.

17 "Suez Canal makes all-time traffic record", Xinhuanews, 02.08.2019, http://www.xinhuanet.com/english/2019-08/02/c 138279360.htm (Erişim Tarihi: 02.07.2020).

${ }_{18}$ Juan Chen, "Strategic Synergy between Egypt "Vision 2030" and China's "Belt and Road" Initiative", Outlines of Global Transformations: Politics, Economics, Law, 2018, Vol 11, No 5, 219-235, s. 226-227.

19 İlhan Tabur, Mehmet Nasih Tağ vd., "Korsanlık ve Deniz Haydutluğu ile Mücadele: Somali Örneği ve Türkiye'nin Katkıları”, Uluslararası Íktisadi ve İdari Bilimler Dergisi, 2016, Cilt 2, Say1 1, 1-20, s. 9-10.

${ }^{20}$ Issaac Kardon, Joshua Wiseman vd., "China's Out of Area Naval Operations: Case Studies, Trajectories, Obstacles, and Potential Solutions”, National Defense University Press Washington, 2010, s. 5.
} 
Bu seferden 9 yıl sonra, Çin, uzak sulardaki ilk deniz üssünü; 2017 yılında Hint Okyanusu'nun batısında Aden Körfezi ile başlayarak, Babülmendep Boğazı üzerinden devam eden ve Süveyş Kanalı geçişiyle Akdeniz'e açılan rota üzerinde, Babülmendep Boğazı'nda Yemen'in karşı kıyısında bulunan Cibuti'de kurmuştur. ${ }^{21}$

2018 yılı itibariyle Cibuti'de Amerikan, İtalyan, Japon, Çin, Fransız askerî üsleri bulunmakta ve Fransız üssünde aynı zamanda Alman-İspanyol askerî personeli, Amerikan üssünde de aynı zamanda İngiliz askerî personel, ikamet etmektedir. Japonya da Cibuti'deki üssü ile ilgili Hindistan ile ortak kullanım anlaşması imzalamıştır. ${ }^{22}$

Bölgede ticari liman inşaatı faaliyetleri de yürüten Çin, Etiyopya ile Cibuti arasında bulunan demiryolu hattının büyük bir bölümünü finanse etmiş, altyapı inşaatını da Çinli firmalar yapmıştır. ${ }^{23}$

$\mathrm{Bu}$ üs, Çinli yetkililer tarafından; klasik anlamda bir askerî üsten ziyade, insani yardımlar ve korsanlığı önleme faaliyetleri gibi uluslararası görevleri gerçekleştirebilmek için kullanılacak bir stratejik güç noktası olarak tanımlanmaktadır.

Cibuti'de kurulan bu stratejik güç noktasının savaşa hazırlık seviyesi ve kapasitesi; büyük çaplı bir operasyonu yürütebilmek veya başka bir devlet ile çatışma halinde tek başına yeterli bulunmamaktadır. Fakat Çin'in Spratly Adaları'nda bulunan üsleri ile Cibuti'deki üssünü bağlayacak yeni stratejik güç noktaları sayesinde, ileride daha da genişlemesi beklenen stratejik güç noktaları ağının bir parçası olması beklenmektedir. ${ }^{24}$

2012 yılından beri, deniz taşımacılığı hizmeti veren firmaları stratejik güç yansıtma görevlerinde destek kuvveti olarak kullanmak için büyük adımlar atan Çin Ordusu, stratejik aktarım destek filosunu sivil firmaların işlettiği gemiler ile çeşitlendirmiştir. Bu çalışmaların meyvesi, Çin

\footnotetext{
${ }^{21}$ Dutton, Isaac B. Kardon vd., a.g.e., s. 3.

22 "Open Source Backgrounder: Djibouti, Foreign Military Bases on the Horn of Africa Who is There? What are They Up To?", Small Wars Fournal, 02.03.2019, https://smallwarsjournal.com/jrnl/art/open-source-backgrounder-djibouti-foreign-militarybases-horn-africa-who-there-what-are (Erişim Tarihi: 29.06.2020).

${ }^{23}$ The Djiboti City - Addis Ababa Transit And Transport Corridor Turning Diagnostics Into Action, UNCTAD, Geneva, 2018, s. 5.

${ }^{24}$ Dutton, Isaac B. Kardon vd., a.g.e., s. 4-5.
} 
Ordusu'na; sivil firmaların işlettiği tanker ve konteyner gemileri ile Çin Donanması'na ait savaş gemilerine, açık denizlerde yakıt ve kuru yük ikmali yapabilmek olarak geri dönmüştür. ${ }^{25} \mathrm{Bu}$ yetenek sayesinde Çin Donanması'nın, ihtiyaç oluşması halinde, Kuşak Yol kapsamında satın aldığı limanlardan sivil gemiler aracılığıyla dolaylı idame desteği alarak açık denizlerde ikmal faaliyeti gerçekleştirebileceği düşünülebilir.

\section{Şekil 2: Çin'in Açık Denizde Savaş Gemilerine Ticari Gemilerden Yakıt ve Kuru Yük İkmali. ${ }^{26}$}

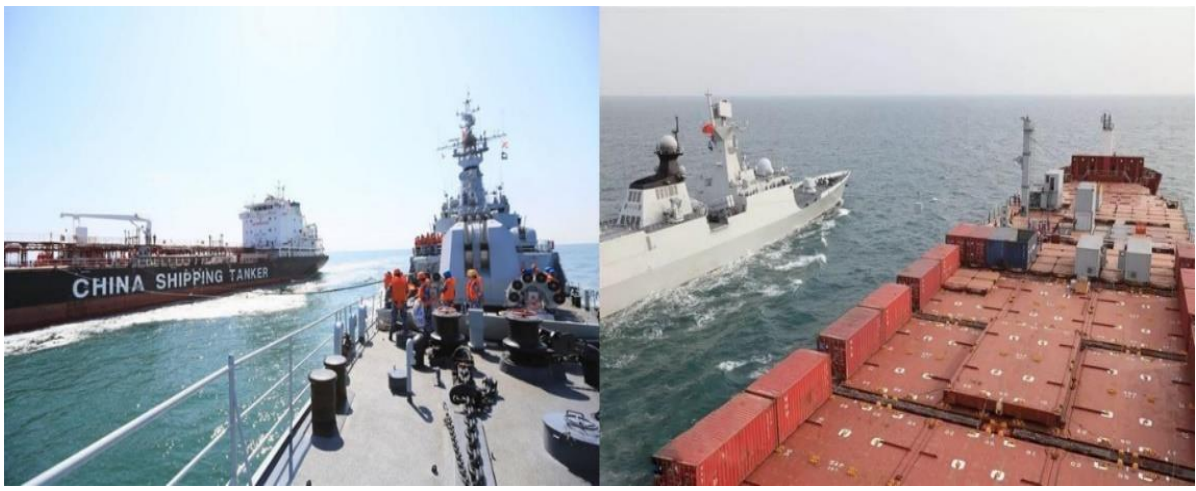

Fakat Çin Donanması'nın; hızlı kapasite artışına rağmen, uzak denizlere sefer yapan bir deniz kuvveti olmak için operasyonel ve lojistik yetenekleri açısından uzmanlar tarafından henüz hazır olmadığı düşünülmektedir. Uzak denizlere yapılacak seferlerde, lojistik destek için sivil kaynak kullanımına bağımlılığ tecrübe sahibi olmaması sebebiyle 2030 yılına kadar uzak denizlerde büyük bir varlık göstermesi beklenmemektedir. ${ }^{27}$

${ }^{25}$ Conor M. Kennedy, "China Maritime Report No. 4: Civil Transport in PLA Power Projection”, U.S Naval War College, Newport, 2019, s. 14-15.

${ }^{26}$ Conor M. Kennedy, a.g.e., s. 14.

27 Chad Peltier, Tate Nurkin vd., "China's Logistics Capabilities for Expeditionary Operations", US.-China Economic and Security Review Commission, Washington, 2020, s. 6. 


\subsection{Malakka Boğazı}

Yol'un ikinci darboğazı ise Hint Okyanusu ile Pasifik Okyanusu'nu ayıran, Malay Yarımadası ile Sumatra arasında bulunan Malakka Boğazıdır. Boğaz hem ekonomik hem de stratejik açıdan dünyanın en yüksek öneme sahip su yollarından biridir. Hint Okyanusu ile Pasifik Okyanusu arasındaki en kısa yol olan boğaz; Çin, Japonya, Güney Kore gibi Asya'nın ekonomik devlerinin Avrupa'ya ulaşabilmesi için ilk adımdır. Ticari gemilerin yaklaşık yarısı ve dünya ticaretinin yaklaşı $\% 15$ 'i bu boğazdan geçmektedir. ${ }^{28}$

Şekil 3: Malakka Boğazı ve Alternatif Rotalar. ${ }^{29}$

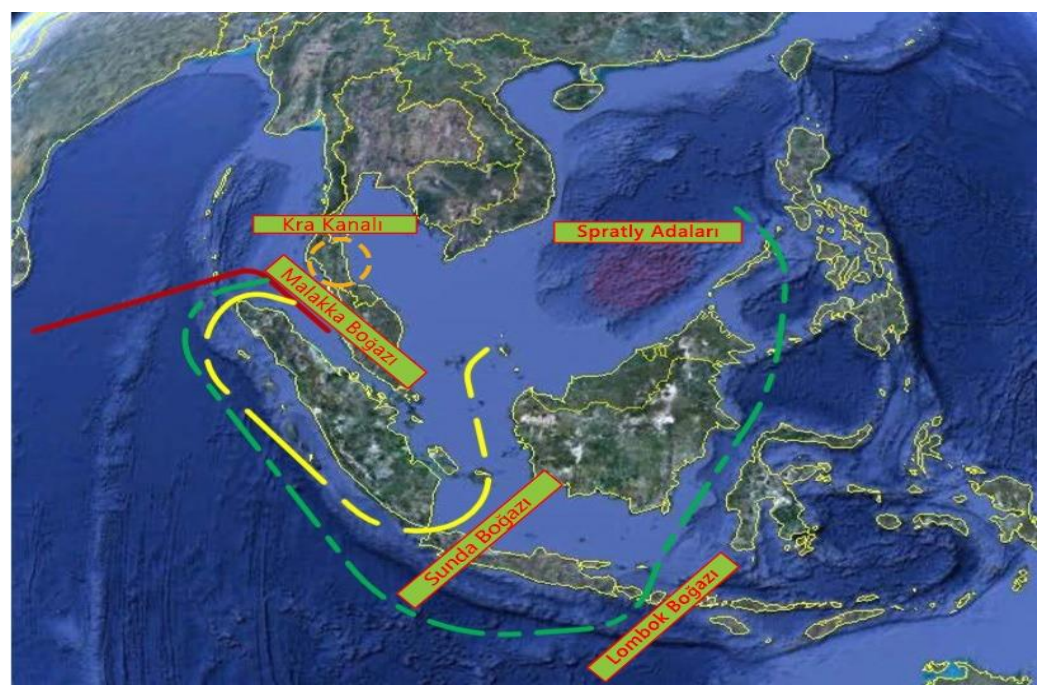

Boğaz, yoğun trafiği sayesinde korsanların da ilgisini çekmektedir. IMO'nun gemilere karşı yapılan korsanlık faaliyetlerini derlediği 2019 raporunda, en fazla korsanlık olayı yaşanan ilk 3 bölge; 67 korsanlık

\footnotetext{
${ }^{28}$ Heather Gilmartin, "The Malacca Straits as Catalyst for Multilateral Security Cooperation”, Sicherheti und Frieden / Security and Peace, 2008, Vol. 26, No. 4, 220-226, s. 221-222.

${ }^{29}$ Xiaobo Qu and Quiang Meng, The Economic Importance of the Straits of Malacca and Singapore: An Extreme Scenario Analysis", Transportation Research Part E Logistics and Transportation Review, 2012, Vol. 48, No. 1, s. 262.
} 
faaliyetiyle Batı Afrika, 45 korsanlık faaliyetiyle Malakka Boğazı ve Singapur, 34 Korsanlık faaliyetiyle Güney Çin Denizi olarak açıklanmıştır. ${ }^{30}$

2008 yılında Malakka Boğazı'nın gemi geçiş kapasitesinin artan gemi trafiğine göre nasıl tepki vereceğini araştıran SimPlus'ın bulduğu sonuçlara göre mevcut trafiğin 5 kat artması halinde bile boğazda kapasite aşımı yaşanması beklenmemektedir. ${ }^{31}$

Bununla beraber, boğazın terör saldırısı veya donanma blokajı gibi bir sebeple kapatılması halinde dünyadaki gemilerin yarısının rota değişikliği yapmak zorunda kalacağı beklenmektedir. İlk alternatif Sunda Boğazı'dır, fakat doğu ucunda 20 metreden az derinliğe sahip olduğu için büyük konteyner gemilerinin çoğu buradan geçemeyebilir. İkinci alternatif ise Lombok Boğazı üzerinden geçmektedir. Rota değişikliği yapılması halinde ise transit süreler artmaktadır. Sunda Boğazı kullanılırsa 1,5 günlük, Lombok Boğazı kullanılırsa da 3,5 günlük bir ortalama transit süre artışı beklenmektedir. ${ }^{32}$

Malakka Boğazı'na olan bu bağımlılığı azaltmak ve iki okyanusun bağlantısını yaklaşık 1000 mil kısaltmak için Tayland'ın ortasından geçecek olan Kra Kanalı projesi gündeme gelmiştir. 25 milyar dolar bütçe ile 10 y1l içinde bitirilebileceği düşünülen proje, 16. yüzyıldan beri tartışılmış, ancak Tayland topraklarını ikiye bölecek oluşu ve Tayland'ın toprak bütünlüğünü tehlikeye atacağ düşüncesi ile şüphe ile yaklaşılmıştır. Bununla beraber kanal projesinin toprak bütünlüğünün bozulacağına dair düşünceler 16 . yüzyıldan kalan endişelerken çözülmesi gereken asıl problemin iktisadi olduğu görülmektedir. ${ }^{33}$

Proje, mevcut rotaları ortadan kaldırmak yerine, bu rotalarla beraber çalışmak üzere planlanmaktadır. Büyük petrol tankerlerinin (Very Large Crude Oil Carrier) Kra Kanalı'nı, konteyner gemilerinin ise Malakka

\footnotetext{
${ }^{30}$ Reports On Acts Of Piracy And Armed Robbery Against Ships Annual Report - 2019, IMO, London, 2019, s. 16.

${ }^{31}$ Working Paper for Carriage Capacity of the Straits of Malacca and Singapore, Simplus Pte. Ltd, Singapore, 2009, s. 13.

${ }^{32}$ Xiaobo Qu and Quiang Meng, a.g.e., s. 261-262.

${ }^{33}$ Fuangfa Amponstira,"Analisis Of Global Connectivity of Kra İthmus Canal Vision", Rajapark Fournal, 2020, Vol. 14, No 33, 298-307, s. 305-306;
} 
Boğazı'nı kullandığı senaryolar üzerinde çalışılmaktadır. ${ }^{34} 2020$ yılı itibariyle Kra Kanalı hala proje safhasındadır. ${ }^{35}$

Çin; 2014 yılında, Kra Kanalı'na benzer bir kanal projesini, Panama Kanalı'nın kuzeyinde, Nikaragua'da gerçekleştireceğini duyurmuş ve bu tarih Panama Kanalı'nın 1914'deki açılışından tam 100 yıl sonrasına denk getirilmiştir. 80 kilometreye yakın uzunluğa sahip olan ve gemilerin neredeyse 1 günde geçtiği Panama Kanalı'na göre, yaklaşık $280 \mathrm{~km}$ uzunluğuyla daha fazla mesafe kat edilmesi gereken bir alternatif olan Nikaragua Kanalı'nın; 13.000 TEU'ya kadar yük taşıyan gemilere geçiş imkânı veren Panama Kanalı'ndan daha az bir kapasite ile 5000 TEU'ya kadar yük taşıyan gemilere geçiş imkânı vermesi beklenmekteydi. Proje ticari açıdan sunduğu çözüm ile birlikte Çin Donanma'sının Orta Amerika üzerinden Atlantik Okyanusu'na geçişini garanti altına almasıyla da stratejik ve askerî öneme sahipti. ${ }^{36}$ Fakat 2014 yılında başlanan projenin inşaat çalışmaları ufak ilerlemelerden sonra ülkedeki iç karışıklar sebebiyle durmuş ve bir daha başlamamıştır. 2019 sonu itibariyle de Nikaragua Hükümeti'nden proje için alınan iznin süresi bitmiştir. ${ }^{37}$

Güney Çin Denizi’ndeki ve Malakka Boğazı üzerindeki ekonomik ve stratejik çıkarlarını korumak amacıyla; Çin, Güney Çin Denizi’nin güneyinde yer alan Spratly Adaları'ndaki mercan resiflerini doldurarak bölgeye yapay adalar inşa etmektedir. ${ }^{38}$ Yaklaşık 425 bin $\mathrm{km}^{2}$ alana yayılmış ufak adalar ve mercan resiflerinden oluşan bu adaların su üstünde kalan toplam yüzeyleri 5 kilometrekareden azdır. ${ }^{39}$

\footnotetext{
${ }^{34}$ Ching-mu Chen and Satoru Kumagai, "Economic Impacts of the Kra Canal: An Application of the Automatic Calculation of Sea Distances by a GIS", Fapan External Trade Organization, Chiba, 2016, s. 7-8.

35 "Time To Revisit Canal Project" Bangkok Post, 20.01.2020, https:/www.bangkokpost.com/ opinion/opinion/1839359/time-to-revisit-canal-project (Erişim Tarihi: 28.06.2020)

${ }^{36}$ Mariano Turzi, "Latin American Silk Road: China And The Nicaragua Canal", Revista de Relaciones Internacionales, Estrategia y Seguridad, 2016, Vol. 12, No. 2, 163-178, s. 165-169.

37 "Is The Gran Canal de Nicaragua Dead In The Water?", Today In Nicaragua, 16.06.2019, https://todaynicaragua.com/is-the-gran-canal-de-nicaragua-dead-in-the-water/ (Erişim Tarihi: 27.06.2020)

${ }^{38}$ Alba Lulia Catrinel Popescu, a.g.e., s. 100-101.

${ }^{39}$ Erik Beukel, "China and the South China Sea: Two Faces of Power in the Rising China's Neighborhood Policy”, Danish Institute for International Studies, Kopenhag, 2010, s. 9-11.
} 
Dünyanın en yoğun ve önemli deniz taşımacılığı rotalarından birinde bulunması, etrafında keşfedilmeyi bekleyen petrol ve doğal gaz yatakları olduğunun düşünülmesi ve balıkçılık kaynakları ve imkânı sunması; adaları, stratejik açıdan daha da önemli hale getirmektedir. ${ }^{40}$ Çin'in bu yapay adaları; askerî uçakların kalkışına elverişli havalimanları, limanlar ve askerî üsler gibi stratejik öneme sahip güvenlik yatırımları da barındırmaktadır. ${ }^{41}$

\section{Şekil 4: Spratly Adaları Mercan Resiflerinin Doldurularak Ada Haline Getirilmesi. ${ }^{42}$}

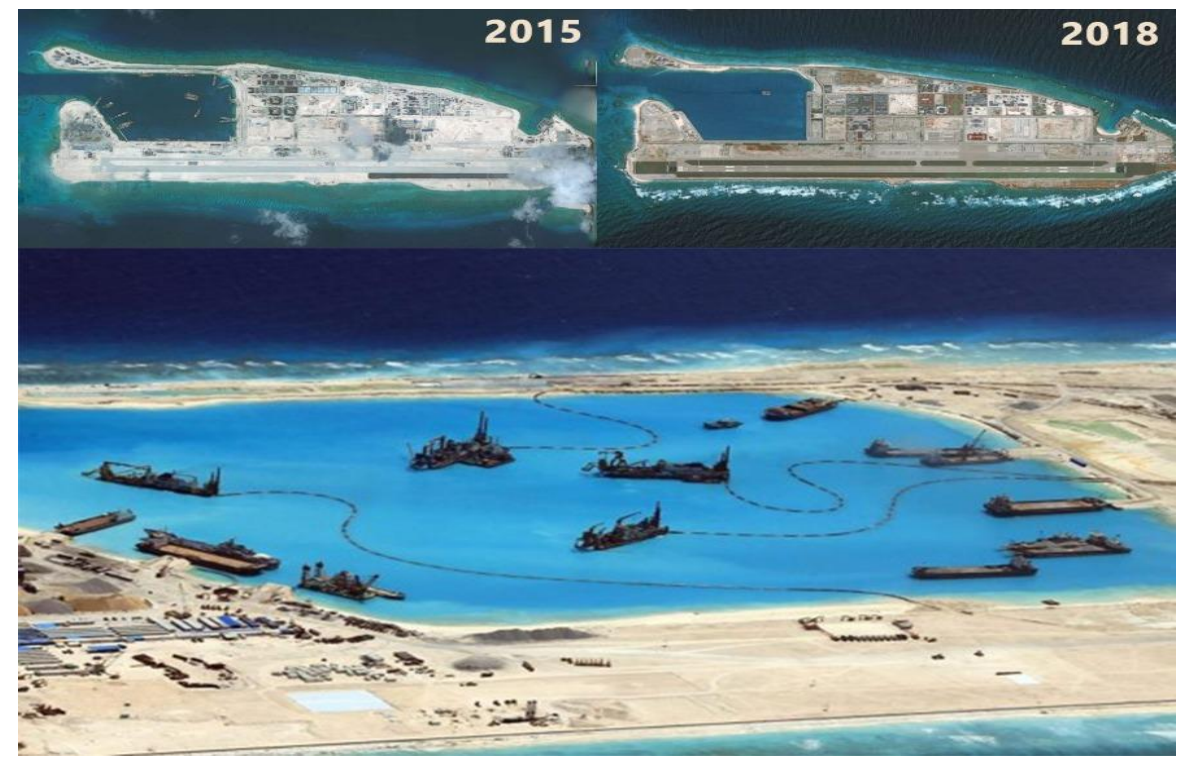

${ }^{40}$ Monjur Hasan and He Jian, "Spratly Islands Dispute in the South China Sea: Potential Solutions", fournal of East Asia and International Law, 2019, Vol. 12, No. 1, 145-168, s. 148-149.

${ }^{41}$ "New Air Bases, Baby Cabbage Key to Chinese Long-Term Claims in South China Sea", U.S. Naval Institute, 03.06.2020, https://news.usni.org/2020/06/03/new-air-bases-babycabbage-key-to-chinese-long-term-claims-on-south-china-sea (Erişim Tarihi: 04.07.2020). 42 "Why the US Navy Sails Past Disputed Artificial Islands Claimed by China", $A B C$ News, 06.03.2019, https://abcnews.go.com/Politics/us-navy-sails-past-disputed-artificial-islandsclaimed/story?id=60993256 (Erişim Tarihi: 23.11.2021). 
Çin'in; Spratly Adaları'nda üslenmesi, Cibuti'deki stratejik güç noktası ve sivil limanlardan aldığı lojistik destek gibi ipuçları değerlendiğinde, gelecekteki deniz lojistik yapılanmasının aşağıdaki dört unsurdan oluşması beklenmektedir.

Tablo 1: Çin'in Gelecekte Beklenen Deniz Yapılanmasının Unsurları. ${ }^{43}$

\begin{tabular}{|l|l|}
\hline \multicolumn{1}{|c|}{ Unsur } & \multicolumn{1}{c|}{ Açıklama } \\
\hline $\begin{array}{l}\text { Ticari Tesis / Dolaylı } \\
\text { Destek }\end{array}$ & $\begin{array}{l}\text { Satın aldığı limanlardan, sivil asker iş birliği ile savaş } \\
\text { gemilerine açık denizde ikmal yapılması. }\end{array}$ \\
\hline $\begin{array}{l}\text { Ticari Tesis / Direkt } \\
\text { Destek }\end{array}$ & $\begin{array}{l}\text { Savaş gemilerinin ticari tesislere demirlemesi yoluyla } \\
\text { alınan lojistik destek. }\end{array}$ \\
\hline Askerî Lojistik Üssü & $\begin{array}{l}\text { Cibuti'de kurulan stratejik güç noktalarına benzer yeni } \\
\text { üsler ve birbirini destekleyen bu yapılardan oluşan ağ. }\end{array}$ \\
\hline Askerî Üs & $\begin{array}{l}\text { Uygun silah sistemleri ile desteklenen, çatışma ve } \\
\text { operasyon kabiliyeti olan üsler. }\end{array}$ \\
\hline
\end{tabular}

Hint Okyanusu'ndan Akdeniz'e geçmek için, Süveyş Kanalı'nın tek alternatifi, mesafeyi ciddi miktarda arttırarak Ümit Burnu'nu dolanıp Cebelitarık Boğazı'nı kullanmak iken; Çin'den Avrupa'ya giden rotada, Malakka Boğazı'nın bypass edilmesi mümkündür. Buna örnek olarak Çin'in Hint Okyanusu'nun batısında Pakistan ile doğusunda ise Myanmar ile yaptı̆̆ çalışmalar örnek gösterilebilir.

Hint Okyanusu'nun batısına açılan CPEC (Çin-Pakistan Ekonomik Koridoru); Çin'in Kaşgar Bölgesi ile Basra Körfezi'nde bulunan Pakistan'ın Gwadar Limanı'nı bağlayarak, deniz taşımacılığı için Malakka Boğazı'na olan bağımlılı̆̆ını azaltabilecek bir proje niteliğindedir. 1 x FEU'nun, Çin'in Kaşgar Bölgesi'nden Avrupa'ya gönderilmesi üzerine yapılan karşılaştırmalarda, koridorun kullanımının, navlun açısından FEU başına $\$ 1350$, transit süreyi kısaltması açısından da yaklaşık 21 gün avantaj

\footnotetext{
${ }^{43}$ Chad Peltier, Tate Nurkin vd., a.g.e., s. 24-26.
} 
sağlayabileceği anlaşılmıştır. ${ }^{44}$ Gwadar Limanı'ndan Çin'e ait ilk ihracat yükü 2016 'da yüklenmiş ${ }^{45}$ ve bölgede proje ile ilgili diğer yatırımlar devam etmektedir. $^{46}$

CPEC’in \$46 milyarlık yatırım bütçesinin yaklaşı \%24'ünün ulaşım altyapısını iyileştirmeye harcanması planlanmaktadır. ${ }^{47}$ Bununla beraber güzergâhın kuzeyinde Keşmir Bölgesi'nden, batısında da Afganistan'dan kaynaklanabilecek güvenlik zafiyetleri de mevcuttur. ${ }^{48}$

Benzer bir yaklaşımla, Çin; Malakka Boğazı'na olan bağımlılığını azaltabilecek yatırımlarına, Hint Okyanusu'nun doğusunda da devam etmektedir; Myanmar üzerinden, inşa edilecek yeni limanların ve altyapı çalışmalarının etkisi ile Malakka Boğazı'nı aşmaya çalışsa da bu koridordaki liman inşaatı 2020 başı itibariyle proje safhasındadır. ${ }^{49}$

\footnotetext{
${ }^{44}$ Khalid Mehmood Alam, Xuemei Li vd., "Impact of Transport Cost and Travel Time on Trade under China-Pakistan Economic Corridor (CPEC)", Fournal of Advanced Transportation, 2019, Vol. 2019, 1-16, s. 14.

45 "Çin, Pakistan Limanı Üzerinden Ticaret Yapmaya Başladı", Anadolu Ajansı, 13.11.2016, https://www.aa.com.tr/tr/dunya/cin-pakistan-limani-uzerinden-ticaret-yapmaya-basladi/68 4844 (Erişim Tarihi: 01.07.2020).

46 "CPEC Projects Progress Update", CPEC, http://cpec.gov.pk/progress-update (Erișim Tarihi: 04.07.2020)

47 Hamzah Rifaat and Tridivesh Singh Maini, "The China-Pakistan Economic Corridor Strategic Rationales, External Perspectives, and Challenges to Effective Implementation", The Stimson Center, Washington, 2016, s. 4.

${ }^{48}$ Riaz Ahmad, Hong Mi, Lloyd W. Fernald, "Revisiting the potential security threats linked with the China-Pakistan Economic Corridor (CPEC)", Fournal of the International Council for Small Business, 2020, Vol 1, No 1, 64-80, s. 72.

49 "China, Myanmar Sign Deals to Spur Belt and Road Project", Anadolu Agency, 18.01.2020, https://www.aa.com.tr/en/asia-pacific/china-myanmar-sign-deals-to-spurbelt-and-road-project/1706737 (Erişim Tarihi: 25.06.2020).
} 


\section{Şekil 5: Çin Pakistan Ekonomik Koridoru ve Myanmar İçin Planlanan Koridor. ${ }^{50}$}

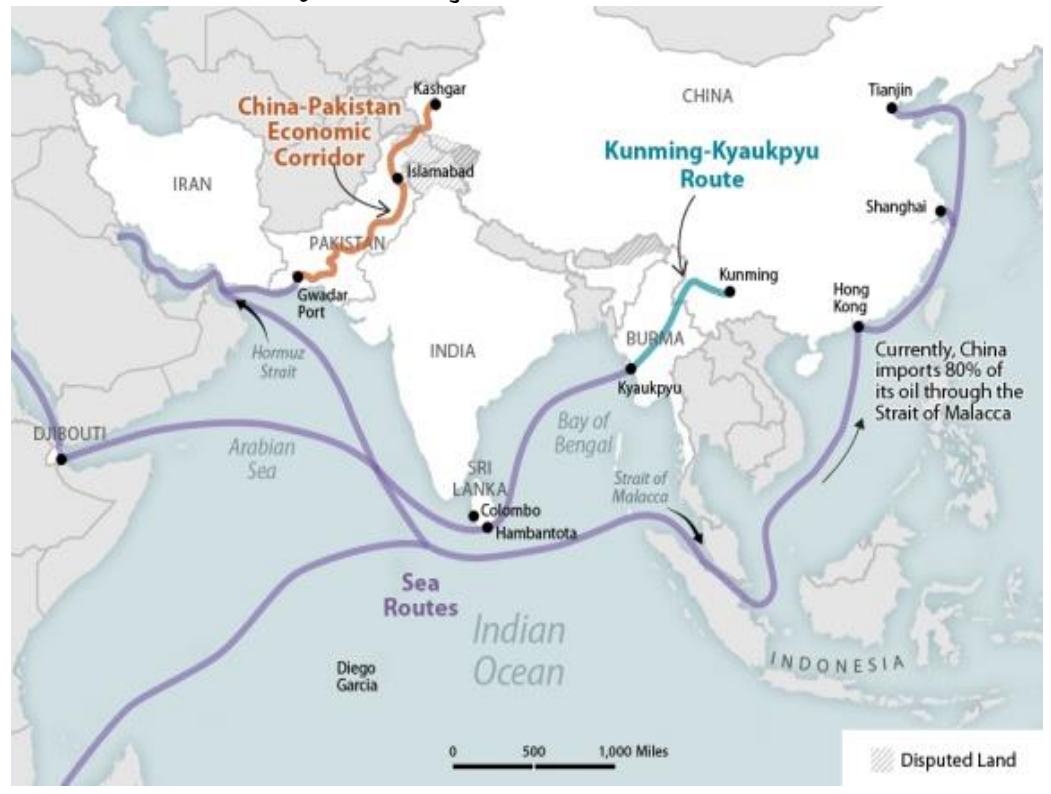

\subsection{Kuzey Deniz Rotası}

Çin'in Kuzey Kutbu'na olan alakası geçen on yıl içinde hızla artmış, buna bağlı olarak kutup bölgeleri 2011'de Çin'in On İkinci Beş Yıllık Planında ilk defa yer almıştır. 2018 yılında Pekin'in Kuzey Kutbu Politikası'nın yayımlanması ve Kutup İpek Yolu'nun, Çin Devlet Başkanı'nın imzaladığı Bir Kuşak Bir Yol Girişimi’nin bir parçası olarak kabul edilmesi ile de resmiyet kazanmıştır. ${ }^{51}$

Kutup İpekyolu'nun deniz rotası olan Kuzey Deniz Rotası'nı kullanan bir gemi, Japonya'nın Yokohoma şehrinden Hamburg'a giderken, Süveyş Kanalı rotasına göre yolculuk mesafesini neredeyse yarı yarıya

\footnotetext{
50 "China Earns Ire of Taiwan, Strengthens Ties With Genocidal Myanmar That Faces ICJ Ruling", Tamilnet, 20.07.2020, https://www.tamilnet.com/art.html?catid=79\& artid=39704 (Erişim Tarihi: 23.11.2021).

${ }^{51}$ Veli Ahmet Çevik ve Tülin Durukan, “Çin'in Kuzey Kutbu'na Olan İlgisi: Kutup İpek Yolu”, Akdeniz İIBF Dergisi, 2020, Cilt 20 Sayı 2, 254-262, s. 260.
} 
azaltmaktadır. ${ }^{52}$ Mesafedeki bu düşüş transit süreye ve maliyete de yansımaktadır; Süveyş Kanalı yerine Kuzey Deniz Rota'sının tercih edilmesi halinde transit sürenin yaklaşık olarak üçte bir oranında azalması, maliyetlerin ise \%30'lara kadar düşmesi mümkündür. ${ }^{53}$

Bununla beraber bu rotanın kendisi bir darboğaza benzetilebilir. 4500 TEU'nun üstünde taşıma kapasitesi olan gemilerin geçemediği bu rota, yılın yaklaşık olarak sadece yarısında aktif olarak kullanılabilmektedir. ${ }^{54}$ Sadece Rus Bayraklı buz kıranların hizmet verebildiği bu hat düşük kapasiteli gemilere hizmet verdiğinden dünya ticareti için ciddi bir alternatif olamamaktadir. ${ }^{55}$

Kuzey Deniz Rotası, ağırlıklı olarak tanker gemileri tarafından tercih edilmiş ve petrol fiyatlarının $\$ 80$ / varil seviyesinin üstüne çıkması halinde, hattın kullanımı, kar etmeye müsait hale gelmektedir. Büyük konteyner gemilerine hem altyapı hem de sefer açısından hizmet veremeyen rota ile ilgili yapılan çalışmalarda; idari problemlerin çözülmesi, petrolün varil fiyatının $\$ 120$ seviyesinin üstüne çıkması ve gereken altyapı hizmetlerinin sağlanması durumunda bile güney rotalarından maksimum $\% 10$ trafik çalabileceği belirtilmiştir. ${ }^{56}$

Fakat bölgedeki buzun erime hızı arttıkça daha büyük gemilere hizmet verebileceği için ticari önemi de giderek artmaktadır ve bu erime neticesinde Bering Boğazı, hattaki yeni darboğaz olarak belirebilir. ${ }^{57}$ Rota ile ilgili yapılan gelecek tahminlerinde erime hızının artmasıyla ve yıl boyu kullanımının mümkün olması halinde Süveyş Kanalı'na veya Ümit Burnu'na göre daha mantıklı bir alternatif olacağı açıklanmıştır. ${ }^{58}$

\footnotetext{
${ }^{52}$ Dmitry Kuzmin, Andrei Baginov vd., "The Northern Sea Route in the conditions of the global economic environment of the transport market", Topical Problems of Architecture, Civil Engineering and Environmental Economics (TPACEE 2018) E3S Web of Conferences, 03-05 December 2018, Moskova, s. 1-2.

${ }^{53}$ Pham Thi Bich Van, Miltiadis Aravopoulos., Feasibility Study on Commercial Shipping in the Northern Sea Route, Yüksek Lisans Tezi, Chalmers University of Technology, Gothenburg, 2019, s. 56-58.

${ }^{54}$ Dmitry Kuzmin, Andrei Baginov vd., a.g.e., s. 2.

${ }^{55}$ Pham Thi Bich Van and Miltiadis Aravopoulos a.g.e., s. 20.

${ }^{56}$ Dmitry Kuzmin, Andrei Baginov vd., a.g.e., s. 4.

${ }^{57}$ Alba Lulia Catrinel Popescu, a.g.e., s. 94.

${ }^{58}$ Inmaculada Martinez-Zarzoso, "Alternative Sea Routes: What Effects on Maritime Trade?”, SAIS Review of International Affairs, 2013, Vol 33, No. 2, 61-74, s. 71.
} 


\section{Şekil 6: Kuzey ve Güney Deniz Rotalar1. ${ }^{59}$}

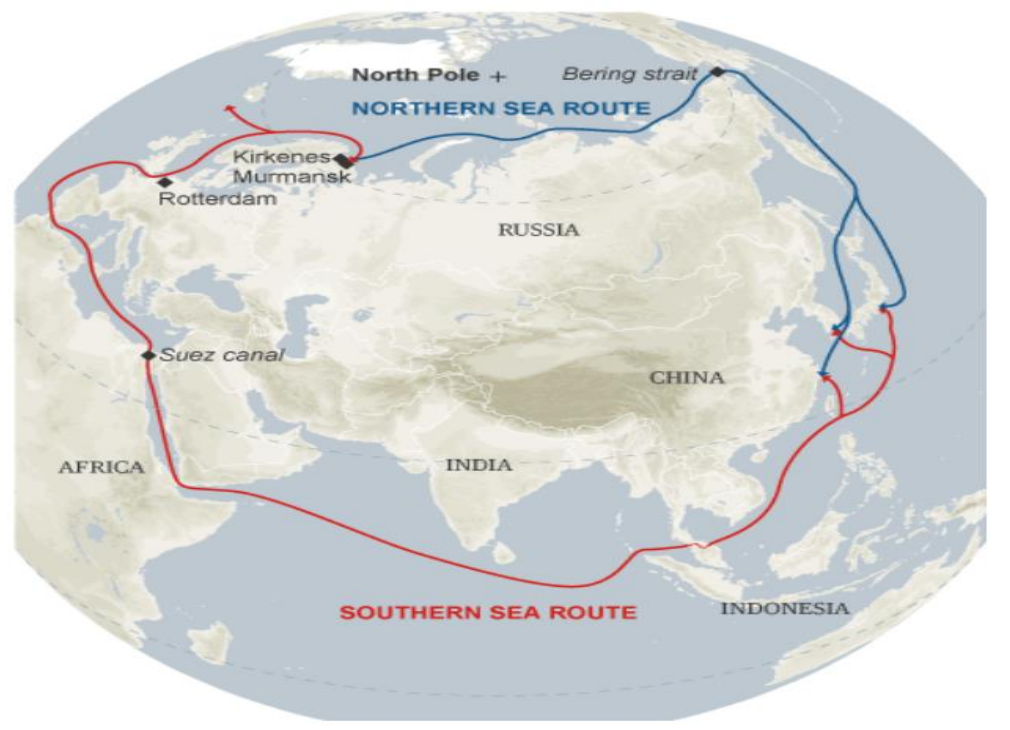

Kuzey Deniz Rotası üzerinde yürütülen çalışmaları raporlayan Nord Üniversitesi Centre for High North Logistics (CHNL)'in internet sitesinde paylaştı̆̆ 1 verilere göre, bu rotadan 2018 yılında transit olarak sadece 27 gemi geçmiştir. ${ }^{60}$ Ağırlıklı olarak genel yük gemileri ve tanker gemilerinden oluşan trafiğin içinde yalnızca bir adet konteyner gemisi vardır, Venta Maersk isimli bu geminin taşıma kapasitesi ise 3600 TEU'dur. ${ }^{61}$ Sitede, 2020 yılının ilk 5 ayında, yaklaşık 10 milyon ton yükün bu rota üzerinden taşındığ bilgisi paylaşılmıştır. ${ }^{62}$ Aynı yılın sadece ocak

59 "Melting Arctic Ice Clears The Way For Supertanker Voyages", The Guardian, 5.10.2011 https://www.theguardian.com/environment/2011/oct/05/melting-arctic-icesupertankers (23.11.2021).

60 "NSR Shipping Traffic - Transits 2018", Centre for High North Logistics, https://arctic-lio.com/nsr-shipping-traffic-transits-2018/ (Erişim Tarihi: 28.06.2020)

61 "VENTA MAERSK", Marine Traffic, https://www.marinetraffic.com/en/ais/details/ships/ shipid:5568438/mmsi:219115000/imo:9775763/vessel:VENTA_MAERSK (Erişim Tarihi: 27.06.2020)

62 "News review of the events on the NSR \#1 May 2020", Centre for High North Logistics, https://arctic-lio.com/news-review-of-the-events-on-the-nsrl-may-2020/ (Erişim Tarihi: 28.06.2020) 
ayında Süveyş Kanalı'ndan yaklaşık 105 milyon ton yük geçtiği düşünülürse Kuzey Deniz Rotası 2020 yılı itibariyle güney rotalarına alternatif olamamaktadır. ${ }^{63}$

\section{Demir İpekyolu Koridorları}

$\mathrm{Bu}$ bölümde öncelikle demiryolu taşımalarının yük taşımacılığı genelinde denizyoluna karşı üstünlükleri açıklanmaya çalışılacak, daha sonra da Avrasya demiryolu taşımacılığının avantajları ve zorlukları genel olarak işlenerek üzerinde anlamlı yük trafiği oluşmuş ana güzergâhlar paylaş1lacaktır. Diğer güzergâhlar ile ilgili genel bir resim çizilmeye çalış1lırken, Türkiye'den geçmesi sebebiyle Bakü-Tiflis-Kars Demiryolu ve Orta Koridor daha detaylı olarak anlatılmaya çalışılacaktır.

Kuşak Yol ismi içinde yer alan Kuşak; Çin'in Avrupa'ya kara koridorları üzerinden bağlanmasını ifade etmektedir. ${ }^{64}$ Kuşak bağlantısının taşımacıllğa yansıyan vizyonu ise Çin'den Avrupa'ya giden demiryolu güzergâhlarında var olan hatların kapasitesini arttırmak veya yenilerini inşa etmek olarak yorumlanabilir. Uzun demiryolu hatları inşa etmek masrafl 1 olmakla beraber, yüksek miktarda yükü uzun mesafelere kara üzerinden taşıyabilmek için maliyet etkin olan tek taşıma şekli demiryoludur. Kuşak Yol Projesi kapsamında, Çin, bu demiryolu hatlarının inşası için kaynak sağlaması nedeniyle, Kuşak bağlantısına dâhil olmak, güzergâhtaki ülkeler tarafından olumlu karşılanmıştır. ${ }^{65}$

Avrasya'yı birbirine bağlayan yeni demiryolu hatları medyada büyük ilgi ile karşılanıyor olsa da Çin ve Avrupa uzun zamandır Trans Sibirya Demiryolu Hattı üzerinden birbirine bağlıdır. Fakat bu hat üzerinden sunulan demiryolu taşımacılığı hizmeti yavaş ve pahalı olduğu için yakın zamana kadar yüksek talep almamıştır. Çin'den yola çıkarak Avrupa'ya giden ilk modern konteyner treni ise, bu yolcuğu 2009 yılında yapmiştır. ${ }^{66}$

${ }^{63}$ Suez Canal Traffic Statistics Monthly Report Fanuary 2020, Suez Canal Authority, Ismailia, 2020, s. 1-3.

${ }^{64}$ The World Bank Group, a.g.e., s.3.

${ }^{65}$ Onur F. Uysal, a.g.e, s. 58.

${ }^{66}$ Peter Bucsky, a.g.e, s. 147. 
Çin'in Avrasya üzerinde demiryolu taşımalarını arttırmak istemesinin altında deniz taşımacılığı konusunda yabancı şirketlere bağımlılığı yatıyor olabilir. Çin'e ait denizcilik firmaları hızla büyüyor olmasına rağmen taşımacılık konusunda Avrupalı denizcilik şirketlerini henüz geçebilmiş değillerdir. Fakat yeni gelişen demiryolu sektöründe, ulusal tecrübelerinden de faydalanarak, Çin'e ait demiryolu şirketleri lider konuma gelebilir. Bir başka sebep olarak, Avrasya deniz rotalarındaki güncel güvenlik sorunları gösterilebilir. Çin ve Avrupa'nın ortasında bulunan Orta Doğu'da yapılacak güvenlik yatırımları demiryoluna kaydırılarak bu sorunlar baypas edilebilir. ${ }^{67}$

Ayrıca küresel ticaret için denizyolu kullanımı, ucuz ve basit olsa da Çin'den Avrupa'ya transit sürelerin 30-40 gün olduğu düşünülürse hiç de hızlı değildir. Çok daha hızlı fakat aynı oranda pahalı olan havayoluna göre daha ucuz olan demiryolu; denizyolundan daha hızlı, havayolundan da daha ucuz olması sebebiyle ilgi çekici bir alternatif oluşturmaktadır. ${ }^{68}$

\subsection{Sorunlar}

Avrasya üzerinde yapılan demiryolu taşımalarında karşılaşılan en büyük teknik sorunlardan biri farklı ray aralıklarıdır. Çin ve Avrupa genellikle standart aralıktaki raylarda $(1435 \mathrm{~mm})$ üzerinde taşıma yaparken, eski Sovyet ülkelerinde ray aralı̆̆ $(1520 \mathrm{~mm})$ daha geniştir. Bu sebeple farklı ray aralıklarına geçişlerde ya bojilerin (İki aksın birbirine sabitlenmesinden oluşan ve vagonun ray düzensizlikleriyle bağını en aza indiren dingil sistemi) değiştirilmesi ya da yükün aktarılması gerekmektedir. Yük aktarma yapılması halinde ise konteynerler büyük avantaj sağlasa da bir konteyner blok treninin aktarma işlemleri 2-4 saat arasında sürmektedir. ${ }^{69}$

Bununla beraber tek seferde daha fazla yük taşımak için kullanılan bir yöntem olan bir vagona 2 konteynerin üst üste koyulması da güzergâh üzerinde bulunan tüneller gibi maksimum yüksekliği kısıtlayan etkenler sebebiyle kullanılamamaktadır. ${ }^{70}$

\footnotetext{
${ }^{67}$ Uysal, a.g.e., s. 57.

${ }^{68}$ Uysal, a.g.e., s. 56.

${ }^{69}$ Hans-Joachim Schramm and Xu Zhang, "Eurasian Rail Freight in the One Belt One Road Era", 30. NOFOMA Conference, 13-15 June 2018, Kolding, s. 7.

${ }^{70}$ Hans-Joachim Schramm and Xu Zhang, a.g.e., s. 7.
} 
Bir başka sorun ise Çin'den Avrupa'ya ihracatın daha fazla olması sebebiyle oluşan trafik dengesizliğidir. Bu dengesizlik; Avrupa'dan çıkan konteynerlerin doluluk oranının Çin'den çıkanlara göre daha az olması sebebiyle, taşıma maliyetlerini etkileyen bir başka faktördür. Demiryollarının Asya'dan Avrupa'ya giderken birçok ülke geçmesi de gümrük işlemleri ile ilgili süreci karmaşıklaştırabilmektedir. ${ }^{71}$

Trenlerin, taşıma yapabilmek için ray gibi kırılgan ve tahrip edilmesi görece kolay bir altyapıya ihtiyaç duyması sebebiyle, güzergâh boyunca oluşabilecek terör saldırıları altyapıya zarar vererek taşımaları engelleyebilir. Avrasya ticaretinin birçok demiryolu güzergâhı üzerinden yapılabiliyor olması güvenlik için gerekli alternatifleri sağlasa da, Çin'in yurtiçi taşımalarda demiryoluna olan aşırı bağımlılığı demiryollarının hedef alınmasına sebep olabilir. Ülkede 40 tondan ağır ve geniş yükleri karayolunda taşıyabilecek çekici ve dorse sayısı çok düşük olduğundan özellikle askerî ve ağır yüklerin taşınması için demiryoluna bağımlılı̆̆ı devam etmektedir. ${ }^{72}$

\subsection{Güzergâhlar}

\subsubsection{Trans Sibirya Hattı}

Rota Çin'in kuzeydoğusunda başlayarak Rusya üzerinden Beyaz Rusya'ya, oradan da Polonya'ya ulaşmaktadır. En büyük avantajı ise görece az sayıdaki sınır geçişidir. ${ }^{73}$ Sibirya'da -40 dereceye kadar düşebilen sıcaklık mutlaka dikkate alınmalıdır. ${ }^{74}$

\footnotetext{
${ }^{71}$ Hans-Joachim Schramm and Xu Zhang, a.g.e., s. 7.

${ }^{72}$ Conor M. Kennedy, a.g.e., s. 23-27.

${ }^{73}$ Uysal, a.g.e., s. 58.

${ }^{74}$ Hans-Joachim Schramm and Xu Zhang, a.g.e., s. 7-8.
} 


\section{Şekil 7: Trans Sibirya Demiryolu Hatt1. ${ }^{75}$}

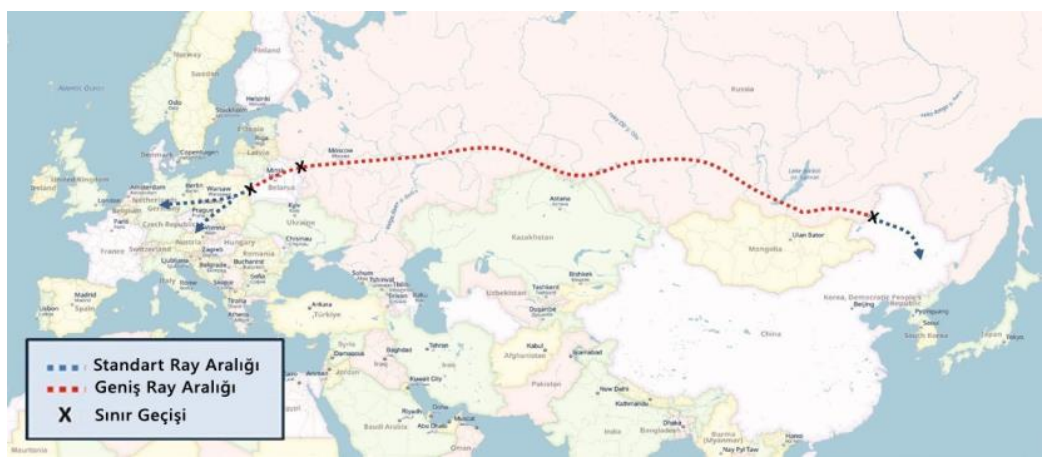

\subsubsection{Kazakistan-Rusya Hattı}

Batı Çin'den başlayarak Kazakistan'a geçer. Buradan da Batı Rusya ve Belarus üzerinden Polonya'ya devam eder. Kazakistan üzerinden bağlantı sağlanması, Çin'in; bütün bölgelerinden bu hatta ulaşımını kolaylaştırmaktadır. ${ }^{76}$ Hatta Avrasya demiryolu hatlarında yapılan konteyner taşımalarının \%95'i Trans Sibirya ve Kazakistan-Rusya hatlarında yapilmaktadir. ${ }^{77}$

\section{Şekil 8: Kazakistan-Rusya Demiryolu Hatt1. ${ }^{78}$}

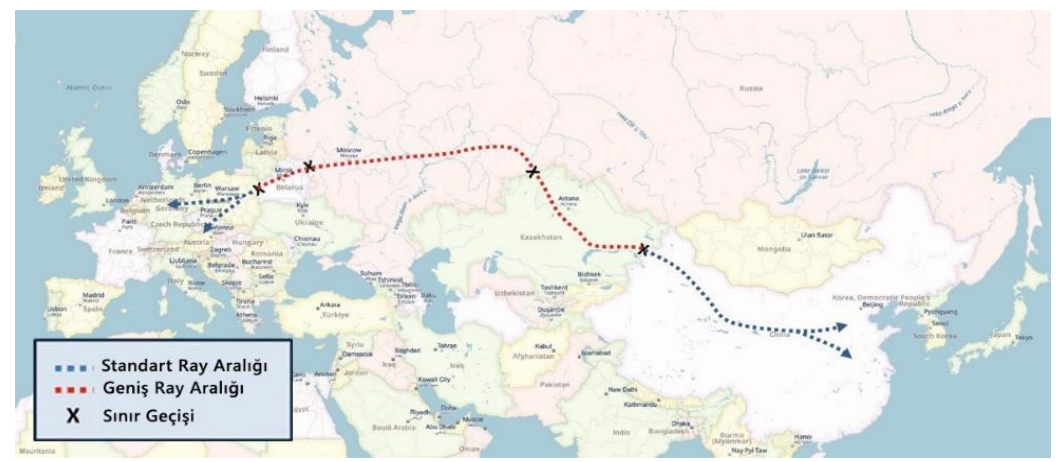

\footnotetext{
${ }^{75}$ Uysal, a.g.e, s. 58.

${ }^{76}$ Uysal, a.g.e., s. 59.

${ }^{77}$ Eurasian Corridors: Development Potential", UIC-Freight Department, Paris, 2020, s. 2.

${ }^{78}$ Uysal, a.g.e., s. 59.
} 


\subsubsection{Kazakistan-Türkmenistan-İran Hattı}

\section{Şekil 9: Kazakistan-Türkmenistan-İran Demiryolu Hattı. ${ }^{79}$}

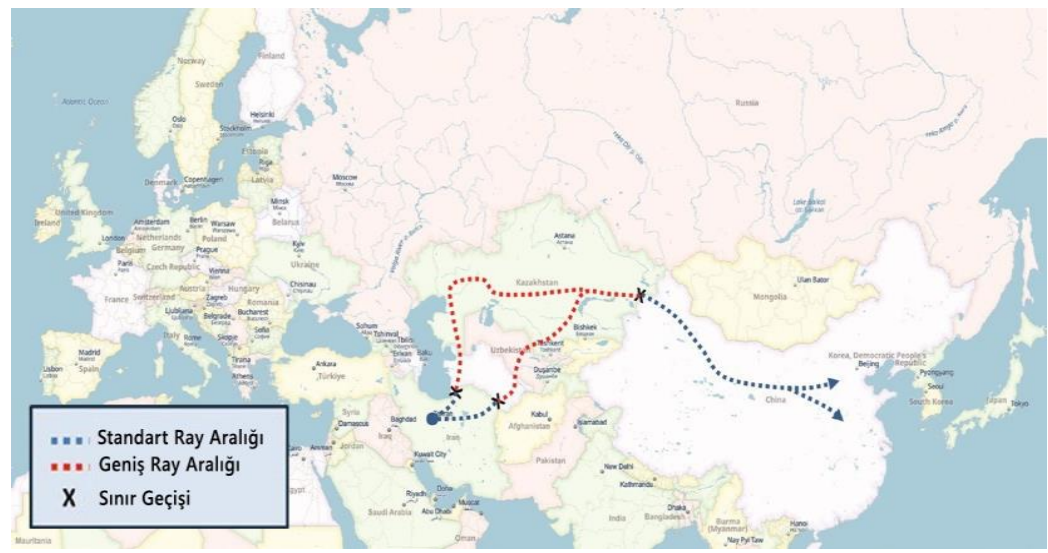

Çin'den Tahran'a 14 günde konteyner taşıyabilmeyi sağlayan bu hat, Çin'in batısında başlayarak Kazakistan'a geçer ve burada 2 ayrı koridor sunar. Bu iki koridor da Türkmenistan üzerinden İran'a geçer. Türkiye'ye geçiş imkânı sunsa da Van Gölü'nün tren feribotlarıyla geçilmesi gerektiğinden, bu hat Çin'den Avrupa'ya Türkiye üzerinden taşıma yapmak için daha önce kullanılmamıştır. ${ }^{80}$

\subsubsection{Bakü-Tiflis-Kars Hattı ve Orta Koridor}

Türkiye'yi Kuşak Yol Orta Koridor'a entegre eden altyapı yatırımı olan BTK (Bakü-Tiflis-Kars) Demiryolu Hattı'nın 2007 yılında ihalesi, 2008 yılında da temel atma töreni yapılmıştır. ${ }^{81} 76$ kilometresi Türkiye'den, 259 kilometresi Gürcistan'dan ve 503 kilometresi ise Azerbaycan'dan geçen hattın toplam uzunluğu 838 kilometredir. ${ }^{82}$

\footnotetext{
${ }^{79}$ Uysal, a.g.e, s. 59.

${ }^{80}$ Uysal, a.g.e., s. 61 .

81 "Demir Ipek Yolu`nda 50 Milyon Ton Yük Taşınacak", Ulaşttrma ve Altyapı Bakanlı̆̆ https://www.uab.gov.tr/basin-aciklamalari/demir-ipek-yolu-nda-50-milyon-ton-yuktasinacak (Erişim Tarihi: 25.06.2020).

82 “Demir Ipekyolu'nda İlk Tren Kalkıyor", Anadolu Ajansı, 29.10.2017, https://www.aa.com. tr/tr/ekonomi/demir-ipekyolunda-ilk-tren-kalkiyor/950718 (Erişim Tarihi: 25.06.2020).
} 
Şekil 10: Bakü-Tiflis-Kars Demiryolu Hattı. ${ }^{83}$

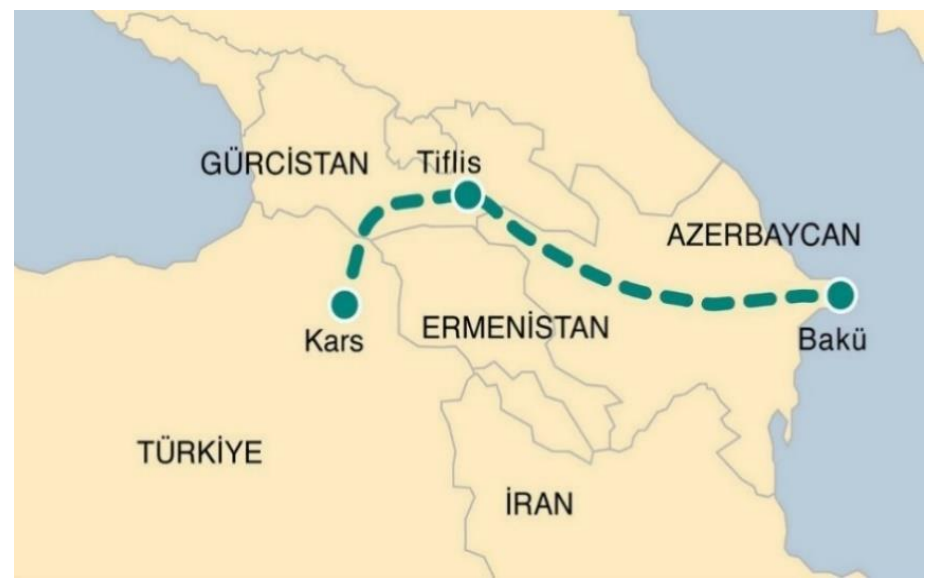

Hattın 2017 yılında açılmasıyla birlikte Türkiye Kuşak Yol Projesi’nin demiryolu ağına entegre olmuş ve 2 yıl içinde bu hatta yaklaşık 275 bin ton yük taşınmıştır. ${ }^{84} 2020$ yılına gelinmesi ile beraber bu rakam 520 bin tonu bulmuştur. ${ }^{85}$ Yapılan en büyük taşıma ise 1050 metre uzunluğundaki, 2400 ton ağırlığındaki ve 50 vagondan teşkil edilen yük treninin Türkiye'den Orta Asya'ya ihracat yüklerini taşımasıyla gerçekleşmiştir. ${ }^{86}$ Kapasite arttırma çalışmaları hem eski Sovyet ülkeleri ile demiryolu taşımacılığında yaşanan farklı ray genişliği problemini çözecek ${ }^{87}$ hem de elleçleme kapasitesini $\operatorname{arttıracak}^{88}$ yatırımlar ile devam etmektedir. BTK Hattı sayesinde

\footnotetext{
83 “Türkiye ile Gürcistan arasında bir ilk Yarın sefere çıkıyor”, Yenişafak, 22.07.2019, https://www.yenisafak.com/ekonomi/turkiye-ile-gurcistan-arasindaki-ilk-ihracat-treniyarin-hareket-edecek-3499347 (Erişim Tarihi: 24.11.2021).

84 "Demir İpek Yolu'nun İki Yillı Serüveni", Anadolu Ajansı, 27.10.2019, https://www.aa.com.tr/tr/ekonomi/demir-ipek-yolunun-iki-yillik-seruveni/1627484\# (Erişim Tarihi: 24.06.2020).

85 "Bakü-Tiflis-Kars Demiryolu Hattında İlave 3 Bin 500 Ton Kapasitesi Artışı Sağlandı", TCDD, http://www.tcddtasimacilik.gov.tr/haber/447/ (Erişim Tarihi: 24.06.2020)

86 "Yeni Bir Rekor Kıran İhraç Treni Yola Çıktı", TCDD, http://www.tcddtasimacilik. gov.tr/haber/440/ (Erişim Tarihi: 26.06.2020).

87 "Bakü-Tiflis-Kars Demir Yolu Hem Kıtaları Hem Rayları Birleştirdi”, Anadolu Ajansı, 31.10.2019, https://www.aa.com.tr/tr/turkiye/baku-tiflis-kars-demir-yolu-hem-kitalari-hemraylari-birlestirdi/1631646 (Erişim Tarihi: 24.06.2020).

88 "Bakü-Tiflis-Kars Demiryolu Hattında İlave 3 Bin 500 Ton Kapasitesi Artışı Sağlandı", TCDD, http://www.tcddtasimacilik.gov.tr/haber/447/ (Erişim Tarihi: 26.06.2020).
} 
Kazakistan'dan Hazar Denizi'ne geçen konteynerler Bakü Limanı'nda tekrar demiryoluna aktarılarak Gürcistan üzerinden Türkiye'ye ulaştırılabilmektedir. ${ }^{89}$ Hazar Denizi'nde 2018 yılında 15 bin TEU konteyner taşınmıştır. ${ }^{90} 2019$ yılında BTK Demiryolu'nun açılmasıla beraber bu rakam 26 bin TEU'ya ulaşmıs ve 2020 yılında bu rakamın 35 bin TEU seviyesine ulaşması hedeflenmektedir. ${ }^{91}$

Hazar Deniz'i üzerinde yapılan konteyner taşımaları için ağırlıklı olarak vagon feribotları kullanılmaktadır. Konteyner taşımacılığ 1 yapmak için kullanılabilecek uygun gemi sayısı yeterli olmadığından konteynerlerin aktarıldığ gemiler iki liman arasında haftada sadece 1 sefer yapmaktadır. ${ }^{92}$

Agshin Mukhtarov'un Hazar Denizi'nde konteyner taşımacılığı konusunda hazırladığı vaka analizi, Hazar Denizi üzerinden taşınan konteynerlerin yıllık 30.000 TEU üzerinde bir hacime ulaştığında, Aktau Limanı ile Bakü Limanı arasında düzenli konteyner taşımacılığ yapmanın finansal açıdan uygun olacağını göstermiştir. Hazar Denizi'nde konteyner gemisi bulunmadığ için 70-100 TEU kapasiteli genel yük gemileriyle yapılan taşımaların; 300-400 TEU arasında bir kapasiteye sahip konteyner gemileriyle yapılması halinde, deniz geçiş navlunu için \%40 ve Çin'den Avrupa'ya yapılan taşımanın toplam taşıma bedeli için de $\% 10$ ile $\% 15$ arasında bir iyileştirme sağlanabileceği çalışmada belirtilmiştir. ${ }^{93}$ Cumhurbaşkanlığ 11. Kalkınma Planı'nda da tespit edilen Orta Koridor darboğazı olan Hazar geçişi için yapılmak istenen iyileştirme, düzenli

89 “Yurtdışı Yük Taşımacılı̆̆ı”, TCDD, http://www.tcddtasimacilik.gov.tr/sayfa/yurtdisiyuk-tasimaciligi/ (Erişim Tarihi: 23.06.2020).

90 "Port of Baku: Everything Comes Together in Alat", Railfreight, 29.10.2019, https://www.railfreight.com/beltandroad/2019/10/29/port-of-baku-everything-comestogether-in-alyat/ (Erişim Tarihi: 27.06.2020).

91 "First In The New Year Sessions of The Working Group and General Meeting of The International Association "TITR" Held In Almaty", Middle Corridor, https://middlecorridor.com/en/pressa/news/130-first-in-the-new-year-sessions-of-theworking-group-and-general-meeting-of-the-international-association-titr-held-in-almaty (Erişim Tarihi: 27.06.2020).

92 "Port of Baku: Everything Comes Together in Alat", Railfreight, 29.10.2019, https://www.railfreight.com/beltandroad/2019/10/29/port-of-baku-everything-comestogether-in-alyat/ (Erişim Tarihi: 27.06.2020).

${ }^{93}$ Mukhtarov Agshin, A case study: Feasibility analysis of container feeder vessel as a short sea shipping service in the Caspian Sea, Yüksek Lisans Tezi, World Maritime University, Malmö, 2018, s. 64-65. 
konteyner taşımacılı̆̆ hizmeti veren bir deniz taşımacıllı̆ı firması kurularak yap1labilir. ${ }^{94}$

Çin'den Avrupa'ya ülkemizden geçerek giden ilk transit tren ise 2019 yılında BTK hattından ülkemize girmiş, Marmaray ile İstanbul Boğazı'nı geçmiş ve Türkiye'den çıkarak Prag'a ulaşmıştır. ${ }^{95}$ Toplamda 820 metre uzunluğunda olan ve 42 tıra denk yükü taşıyan bu tren ile birlikte transit kullanıma açılan hatta 3-4 yıl içinde yıllık 1000 tren geçişine ulaşılması hedeflenmektedir. ${ }^{96}$ Hat üzerinde yapılan taşımaların zaman içinde artması ve bu sayede daha yaygın kullanıma ulaşması beklenmektedir.

Türkiye'nin transit güzergâh olarak bu geçiş seviyesini sağlayabilmesi için de Avrupa'ya demiryolu bağlantısı olan Halkalı-Kapıkule hattında yatırımlar sürmektedir. ${ }^{97}$

\section{Şekil 11: Türkiye'den Geçen Orta Koridor. ${ }^{98}$}

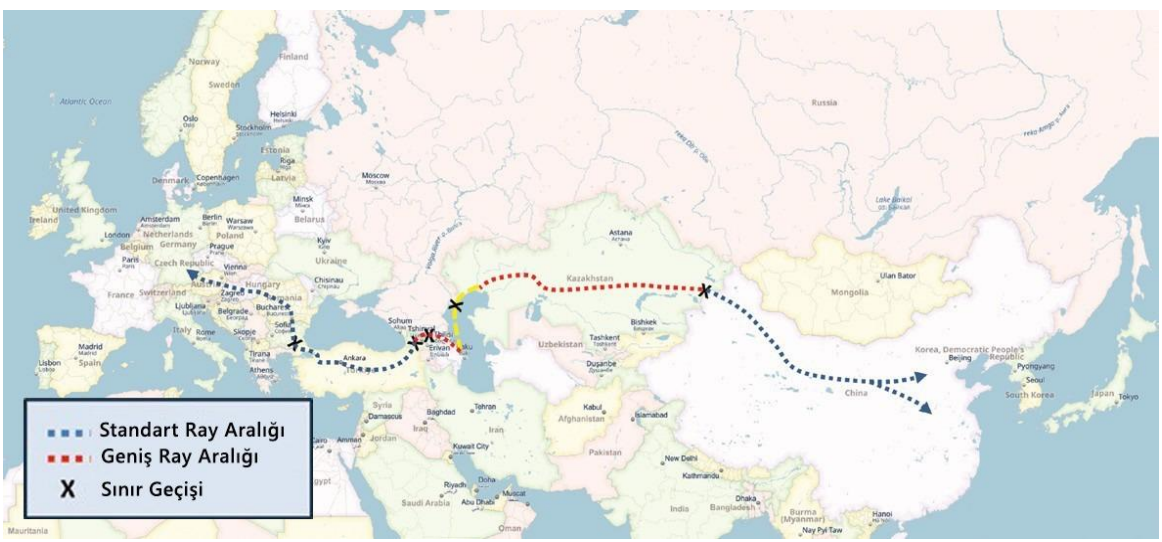

94 T.C. Cumhurbaşkanlığı Strateji ve Bütçe Başkanlığı, “11. Kalkınma Planı”, 2019, T.C. Cumhurbaşkanlığı, Ankara, s.73.

95 "Bir Kuşak Bir Yol Projesi'nin İlk Transit Treni Avrupa'ya Uğurlandı", TCDD, http://www.tcddtasimacilik.gov.tr/haber/355/ (Erişim Tarihi: 24.06.2020)

96 “Türkiye Çin'e 'İhracat Treni' Gönderecek", Anadolu Ajansı, 22.12.2019, https://www.aa.com.tr/tr/turkiye/turkiye-cine-ihracat-treni-gonderecek/1680753

(Erişim Tarihi: 25.06.2020).

97 "Halkalı-Kapıkule Hizlı Demiryolu Hattının Temeli Atıldı", TCDD, http://www.tcddtasimacilik.gov.tr/haber/345/ (Erişim Tarihi: 26.06.2020).

${ }^{98}$ Onur F. Uysal, “The Iron Silk Road: How will Turkey be Involved?", Caucasus International Dergisi, 2016, Cilt 6, s. 59. 
Marmaray'ın yük taşıma kullanımına açılmasıyla beraber yurt içinde demiryolu yük taşımacılığı hareketlenmiş ve yurt içi hattında da kıtalar arası geçiş Marmaray ile sağlanmaya başlamıştır. ${ }^{99}$ Aktif olarak kullanılan BTK Hatt1 ve Anadolu'dan da Avrupa ülkelerine ihracatta demiryolu kullanımının kolaylaşmasıyla beraber son kullanıcılar için artık yeni bir çözüm oluştuğunu söylemek mümkün hale gelmiştir.

2011 yılında, demiryolu ile karayoluna kıyasla kilometre başına yaklaşık 10 kat daha fazla yük taşınmıştır. ${ }^{100}$ Bu noktadan hareketle BTK Hattı'nın teşkilinden önce çoğunlukla karayoluyla ulaşılan Orta Asya'da, ticaret kapasitesini arttırmak için yeni fırsatlar doğabilir. Aynı zamanda denize sınırı olmayan bölge ülkelerinin ihracat ve ithalat için Türkiye'nin limanlarını çok daha yüksek kapasitelerle kullanabilecek olması karşılıklı bir fayda sağlayabilir. Afganistan'1 Türkmenistan üzerinden BTK Hattı ile Türkiye'ye bağlayan Lapis Lazuli Hattı bu firsatların özeti olarak gösterilebilir. ${ }^{101}$

\section{Bulgular}

Dünya emtia ticaret hacminin yaklaşı $\% 80$ 'i, pahasının ise yaklaşık \%70'i denizyolu ile taşınmaktadır. ${ }^{102} \mathrm{Bu}$ bilgi ışı̆̆ında düşünüldüğünde kapasite açısından denizyolu ile yarışabilecek başka bir taşıma modu olmadığı açıkça öngörülebilir.

İki taşıma modu arasında Avrasya ticareti için kullanım hacmi farkını anlayabilmek adına güncel kullanım miktarlarını incelemek faydalı olabilir. 2017 yılında Avrasya demiryolu hatlarında yapilan toplam konteyner taşımacılığ 279 bin TEU seviyesindedir. ${ }^{103}$ Aynı yıl Asya-Avrupa hattında denizyolu ile yapılan konteyner taşımacılığ 1 ise yaklaşık 23 milyon TEU

\footnotetext{
99 “Marmaray'dan Geçen İlk Yurt İçi Treni Tekirdağ’a Ulaştı”, Anadolu Ajansı, 09.05.2020, https://www.aa.com.tr/tr/turkiye/marmaraydan-gecen-ilk-yurt-ici-treni-tekirdaga-ulasti/ 1834758 (Erişim Tarihi: 27.06.2020).

${ }^{100}$ Railway Handbook 2014, IEA-UIC, Paris, 2014, s. 5.

101 “Afganistan Lapis Lazuli güzergahıyla Türkiye'ye bağlanacak”, Anadolu Ajansı, 13.12.2018, https://www.aa.com.tr/tr/ekonomi/afganistan-lapis-lazuli-guzergahiylaturkiyeye-baglanacak/1337951 (Erişim Tarihi: 29.06.2020)

${ }^{102}$ Reviev Of Maritime Transport 2017, UNCTAD, Geneva, 2017, s. X.

${ }^{103}$ UIC-Freight Department, a.g.e., s. 3.
} 
olarak gerçekleşmiştir. ${ }^{104}$ Yani 2017 yılında Avrasya'da denizyolu ile taşınan konteyner miktarı demiryolu ile taşınandan yaklaşık 83 kat daha fazladır.

Şekil 12: Yıllara Göre Denizyolu ile Yapılan Konteyner Taşımaları. ${ }^{105}$

Doğu-Batı Aksı Ana Ticaret Rotalarında Konteyner Taşımacılığı, 2014-2017 (Milyon TEU)

\begin{tabular}{|c|c|c|c|c|c|c|}
\hline YIL & $\begin{array}{l}\text { Trans Pasifik } \\
\text { Doğu ìstikameti }\end{array}$ & Batı İstikameti & $\begin{array}{l}\text { Asya-Avrupa Doğu } \\
\text { İstikameti }\end{array}$ & Westbound & $\begin{array}{l}\text { Trans Atlantik } \\
\text { Doğu İstikameti }\end{array}$ & Batı İstikameti \\
\hline & $\begin{array}{l}\text { Doğu Asya'dan } \\
\text { Kuzey } \\
\text { Amerika'ya }\end{array}$ & $\begin{array}{l}\text { Kuzey } \\
\text { Amerika'dan } \\
\text { Doğu Asya'ya }\end{array}$ & $\begin{array}{l}\text { Kuzey Avrupa'dan } \\
\text { ve Akdeniz'den } \\
\text { Doğu Asya'ya }\end{array}$ & $\begin{array}{l}\text { Doğu Asya'dan } \\
\text { Kuzey Avrupa'ya } \\
\text { ve Akdeniz'e }\end{array}$ & $\begin{array}{l}\text { Kuzey } \\
\text { Amerika'dan } \\
\text { Kuzey Avrupa'ya } \\
\text { ve Akdeniz'e }\end{array}$ & $\begin{array}{l}\text { Kuzey } \\
\text { Avrupa'dan ve } \\
\text { Akdeniz'den } \\
\text { Kuzey Amerika'ya }\end{array}$ \\
\hline 2014 & 15.8 & 7.4 & 6.8 & 15.2 & 2.8 & 3.9 \\
\hline 2015 & 16.8 & 7.2 & 6.8 & 14.9 & 2.7 & 4.1 \\
\hline 2016 & 17.7 & 7.7 & 7.1 & 15.3 & 2.7 & 4.3 \\
\hline 2017 & 17.9 & 8.2 & 7.6 & 15.5 & 2.9 & 4.5 \\
\hline
\end{tabular}

2018 yılına gelindiğinde Avrasya'da denizyolu ile yapılan konteyner taşımacılığ 24 milyon TEU seviyesine ulaşmıştır. ${ }^{106}$ Aynı yıl demiryolu taşımacılığ 1 ise toplam 345 bin TEU seviyesine çıkmıştır. ${ }^{107} 2018$ yılının konteyner taşımacılık verilerinin karşılaştırılmasıyla da deniz yolu ile yapılan konteyner taşımalarının, demiryolu ile yapılan konteyner taşımalarından yaklaşık 70 kat daha fazla olduğu anlaşılmaktadır. Bununla beraber demiryolu taşımacılığının Avrasya'da, ticaretten aldığ payın hızla arttığı unutulmamalıdir.

\footnotetext{
${ }^{104}$ UNCTAD, a.g.e., s. 12.

${ }^{105}$ Reviev Of Maritime Transport 2017, UNCTAD, Geneva, 2017, s. 12.

${ }^{106}$ Reviev Of Maritime Transport 2019, UNCTAD, Geneva, 2019, s. 13.

${ }^{107}$ UIC-Freight Department, a.g.e., s. 3.
} 


\section{Şekil 13: Yıllara Göre Avrasya Hatlarında} Demiryolu ile Yapılan Konteyner Taşımaları. ${ }^{108}$
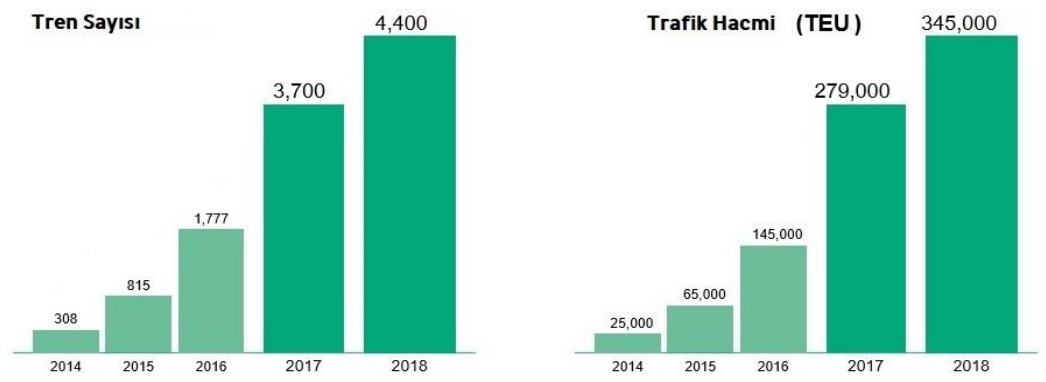

Avrasya demiryolu hatlarında yapılan konteyner taşımaları 2014 yılında 25 bin TEU seviyesinde iken; demiryolu taşımalarına artan rağbet, yeni hatların açılması ve Kuşak Yol'un ivmesi sayesinde 2018 yılına gelindiğinde 345 bin TEU seviyesine kadar yükselmiştir. Hatlarının gelişme potansiyelini araştıran UIC'nin (International Union of Railways) 2020 yılında yayınladığı raporda, 2030 yılı için en iyi durum senaryosunun gerçekleşmesi halinde Avrasya'da demiryolu taşımalarının, 2 milyon TEU hacmini aşabileceği belirtilmiştir. ${ }^{109}$ Avrasya demiryollarında yapılan konteyner taşımacılığının uzun vadede 2 milyon TEU seviyesini aşabileceği, Avrasya Kalkınma Bankası'nın hazırladığı "Silk Road Transport Corridors: Assessment of Trans-EAEU Freight Traffic Growth Potential" isimli çalışmada da belirtilmiştir. ${ }^{110}$

Çin Halk Cumhuriyeti'nin Gümrükler Genel İdaresi tarafından paylaşılan ticaret faaliyetlerinin taşıma modları arasında dağılımına dair veriler, Peter Bucsky tarafından hazırlanan "The İron Silk Road: How Important is It" isimli çalışmada derlenmiş ve ithalat-ihracat faaliyetlerinde seçilen taşıma aracı ezici bir üstünlükle gemi olmuştur. ${ }^{111}$ Tren ile yapılan taşımalar ise toplam ithalat-ihracat faaliyetlerinin yaklaşık \%2'sini

\footnotetext{
${ }^{108}$ UIC-Freight Department, a.g.e., s. 3.

${ }^{109}$ UIC-Freight Department, a.g.e. s. 3.

110 Silk Road Transport Corridors: Assessment of Trans-EAEU Freight Traffic Growth Potential, Eurasian Development Bank, St. Petersburg, 2018, s. 53.

${ }^{111}$ Peter Bucsky, "The iron Silk Road: how important is it?", Area Development and Policy, 2020, Vol. 5, No. 2, s. 149.
} 
oluşturmaktadır. Aynı çalışmada Çin ile Avrupa Birliği arasındaki ticaretinin verileri de derlenmiş ve 2018 yılında gerçekleşen toplam ticaretin sadece $\% 1,4$ 'ü demiryolu ile taşınmaktadır. ${ }^{12}$

Hans-Joachim Schramm'in ve Xu Zhang'in 2018 y1lında 10 ton emtia yüklenmiş bir FEU'nun Şangay'dan Hamburg'a taşınmasını konu alan çalışmasında ise Avrasya'da demiryolu taşımacılığı hizmetinin havayolundan yaklaş1k \%80 daha ucuz ve denizyolundan ortalama 2 kat hızlı olduğu belirtilmiştir. Aynı çalışmada; yüksek zaman hassasiyeti olan taşımalarda, malın kilogram pahası $1.23 \$-10.78 \$$ aralığında ise ve düşük zaman hassasiyeti olan taşınmalarda, malın kilogram pahası $2.46 \$-21.78$ \$ aralığında ise demiryolu kullanımının en uygun seçim olacağ belirtilmiştir. $^{113}$

\section{Şekil 14: Çin'in Küresel Ticaret’te Taşıma Modu Dağılımı. ${ }^{114}$}

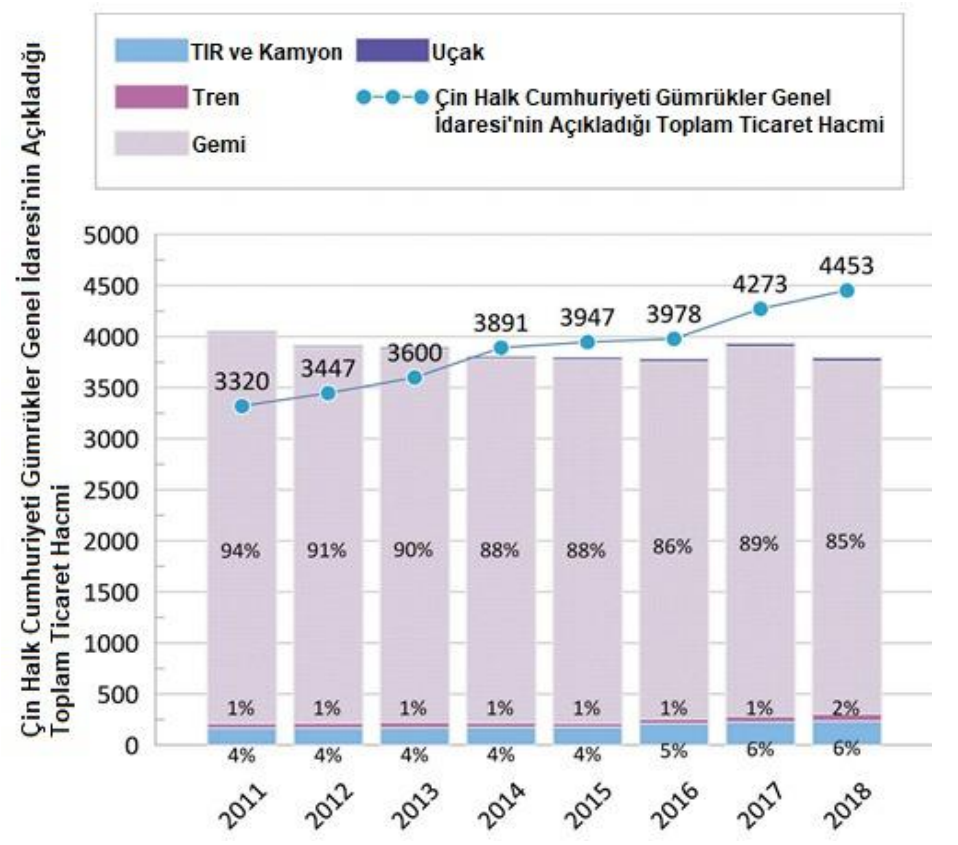

${ }^{112}$ Bucsky, a.g.e., s. 156.

${ }^{113}$ Hans-Joachim Schramm and Xu Zhang, a.g.e., s. 15.

${ }^{114}$ Bucsky, a.g.e., s. 150. 
Denizyolu konteyner taşımacılı̆̆ının geleceği ile ilgili yapılan gelecek projeksiyonlarında 2020-2030 arasında yıllık tahmini $\% 2.5$ ile $\% 5.1$ büyüme beklentisi mevcuttur. ${ }^{115} 2020$ yılında dünya genelinde denizyolu ile taşınan konteyner miktarı ise yaklaşı 144 milyon TEU olmuştur. ${ }^{116} \mathrm{Bu}$ bilgiler ışığında Avrasya'da uzun vadede demiryolu ile yapılan konteyner taşımalarının 2 milyon TEU hacmini aşması halinde bile; denizyolu ile rekabet edemeyeceği anlaşılmaktadır.

\section{Şekil 15: Çin-Avrupa Birliği Ticareti, Yıllara Göre Taşıma Modu Dağılımı. ${ }^{117}$}

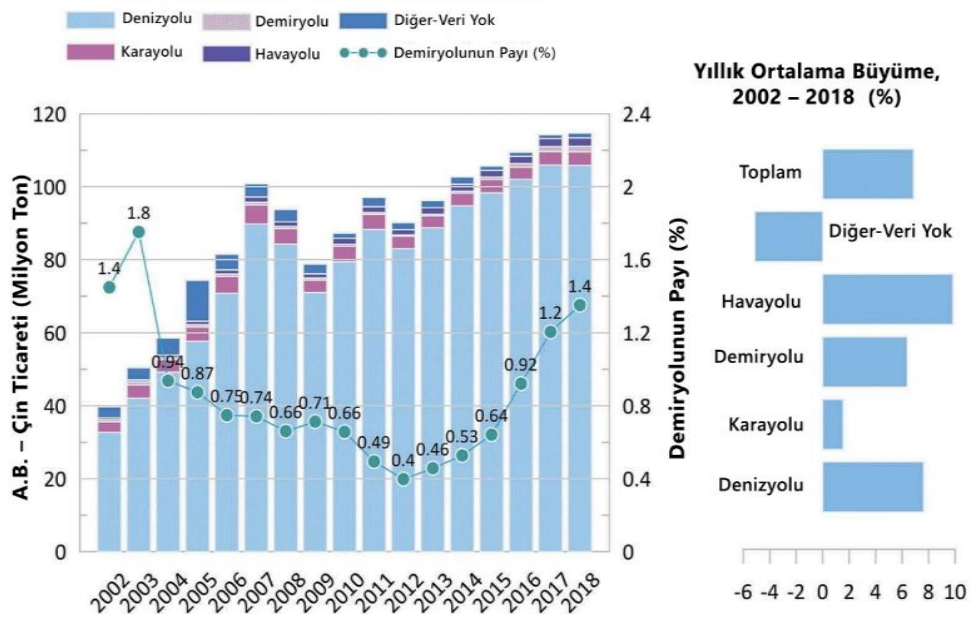

\section{Analiz}

Araştırma ile elde edilen bulgular, Demir İpekyolu'nun; Deniz İpekyolu'na kapasite açısından rakip olamayacağını ortaya çıkartmıştır. Demir İpekyolu; Avrasya demiryollarını kullanan bir çatı organizasyon olarak kabul edilerek, kendine ait dinamikleri SWOT analizi yöntemi ile özetlenmeye çalışılacaktır.

115 DNV, “Maritime Forecast To 2050 Energy Transition Outlook 2020”, Hamburg, 2020, s. 100 .

${ }^{116}$ Reviev Of Maritime Transport 2017, UNCTAD, Geneva, 2017, s. 14.

${ }^{117}$ Bucsky, a.g.e., s. 156. 
SWOT analizi sonucunda demiryolu kullanımının zayıf ve tehditler başlığı altında yer alan konular giderildikçe kullanım oranının daha da artarak iyimser senaryolardaki trafik rakamlarını yakalayacağı düşünülmektedir.

Ayrıca; Demir İpekyolu'nun, b tipi envanter olan, yükte ve pahada ortalama değerlere sahip yükler için ideal olduğu gözlemlenmiştir. Özellikle havayolunun pahalı, denizyolunun ise yavaş kaldığı taşımalar için uygun bir çözüm olduğu anlaşılmaktadır.

\section{Tablo 2: Demir İpekyolu SWOT Analizi}

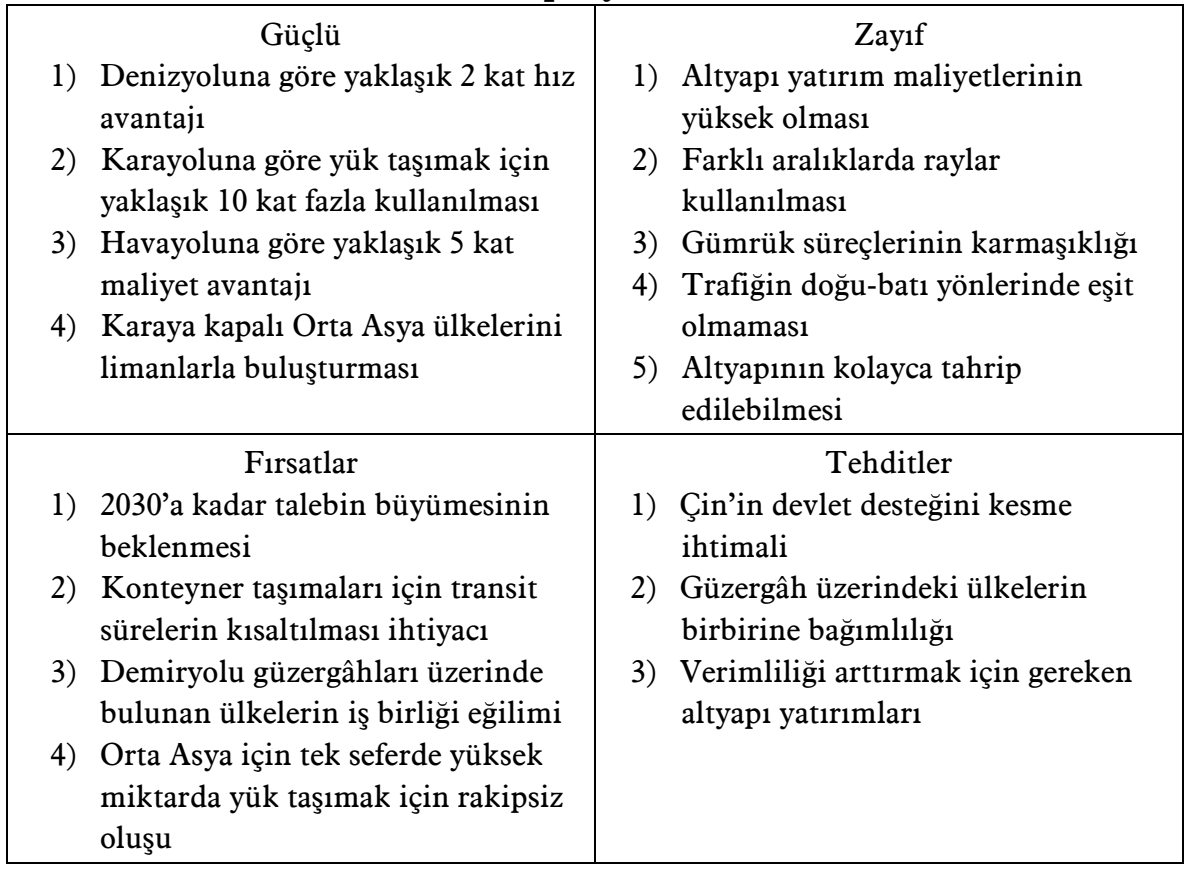

\section{Tartışma ve Sonuç}

Avrasya'da yapılan uluslararası ticaret için demiryolu kullanımı Kuşak Yol'dan önce de uygulanmıştır. Japonya'nın, Güney Kore'nin, Finlandiya'nın; farklı zaman dilimlerinde, ağırlıklı olarak Trans Sibirya 
Demiryolu Hattı üzerinden oluşturduğu konteyner trafiği birkaç yüz bin TEU kadar çıkmayı başarsa da çoğunlukla navlunlarda yaşanan yükselmeler sebebiyle konteyner trafiği zamanla azalmıştır. ${ }^{118}$

Aynı zamanda Çin'in demiryoluna sağladığı devlet desteğinin navlunları iyileştirdiği bilinmektedir. ${ }^{119} \mathrm{Bu}$ desteği yakın gelecekte Covid19 salgını sebebiyle kesmesi halinde navlunların artacağı düşünülebilir.

UIC tarafından hazırlanan raporda Çin'in demiryolu taşımalarında desteği kesmesi durumunda beklenen düşüş dikkate alındığında Kuşak Yol ile beraber tekrar başlayan demiryolu taşımacılığının yükselişi, önceki denemeler gibi zamanla trafik kaybına uğrayabilir. ${ }^{120}$

Demiryolu ile karayoluna kıyasla kilometre başına yaklaşık 10 kat daha fazla yük taşınabilir. ${ }^{121} \mathrm{Bu}$ sayede Orta Asya ülkeleriyle BTK hattı sayesinde; ticaret hacmi artabilir, daha önce mümkün olmayan miktarda dökme ve konteynerize yük taşıması yapılabilir. Ayrıca, BTK Hattı, Orta Asya'da denize kıyısı olmayan ülkeleri Türkiye limanları üzerinden küresel ticarete entegre edebilir. Fakat doğu batı yönünde eşit olmayan trafik demiryolu için ciddi bir dezavantaj teşkil etmektedir. Çin'den çıkan yük trenleri ortalama 80 TEU taşırken, aynı hatta taşıma yapan konteyner gemilerin taşıma kapasitesi 20.000 TEU'yu aşmıştır. ${ }^{122} \mathrm{Bu}$ sebeple boş konteynerlerin taşınması demiryolu için ciddi maliyetler oluştururken denizyolu için çok daha düşük maliyetler ile yapılabilmektedir.

Bütün bunları dikkate alarak, yapılan araştırma sonucunda, Demir İpekyolu'nun Deniz İpekyolu'na kapasite açısından ikame olamayacağı değerlendirilmektedir. Dünya ve Avrasya ticareti için yakın gelecekte de denizyolunun ezici bir üstünlükle en çok tercih edilen taşıma modu olacağını söylemek mümkündür. Demir İpekyolu, mevcut taşıma beklentilerine kendine özgü çözümler sunan bir alternatif olarak değerlendirilmelidir. Demir İpekyolu ile gelişen fırsatlar, deniz darboğazlarından olan Süveyş

\footnotetext{
${ }^{118}$ Bucsky, a.g.e., s. 150-152.

${ }^{119}$ Bucsky, a.g.e., s. 162.

${ }^{120}$ UIC-Freight Department, a.g.e., s. 6.

${ }^{121}$ IEA-UIC, a.g.e., s. 5.

122 "World's largest containership makes its first crossing through Suez Canal", Offshore Energy, 31.08.2021, https://www.offshore-energy.biz/worlds-largest-containership-makesits-first-crossing-through-suez-canal/ (Erişim Tarihi: 24.11.2021).
} 
Kanalı'nın kapanmasıyla daha iyi anlaşılmıs olabilir. ${ }^{123}$ Denizyoluna bağımlılığı bir nebze de olsa düşürmesi sayesinde daha yüksek trafik rakamları yakalayabilir.

Avrasya'da yakın gelecekte 1 milyon TEU'yu aşması beklenen demiryolu konteyner taşımacılı̆̆ının, özellikle Orta Koridor üzerinden Türkiye'ye sağlayabileceği büyük firsatlar göz ardı edilmemelidir. Bu firsatı kaçırmamanın yolu da taşıma kapasitesini arttıracak altyapı yatırımlarından geçiyor olabilir. Çünkü Avrasya'da yapılan demiryolu taşımalarının çoğu mevcut hatlar kullanılarak yapılmaktadır ve bu hatların kapasitesi uzun zamandır arttırılmamıştır. ${ }^{124}$

\section{Summary}

Turkey is a country, which sits between the Europe and China. With the first train from China to Europe via Turkey, a new era started for rail transportation on Iron Silk Road. The new era has come with many questions as well. The rising public and academic attention about the topic is the backbone of importance for this study. The rivalry between rail transportation and ocean transportation could get affected by modern standards and technology.

This paper aims to research whether railway transportation can be a competitor to ocean transportation for Eurasian trade in terms of carrying capacity. In order to research topic, the method that has been used is archive research and the secondary data collected from various reports from UN, the Eurasia Development Bank, etc. Related papers have also been considered as a data source and container transportation is considered as the main competing area for railway and ocean transportation.

Through the research, security disturbance for both transportation methods are also mentioned. The Road on BRI means the seaway from China to Europe and the Road refers to two maritime straits are considered as maritime chokepoints. One of them is Suez Canal and China has invested

123 “Süveyş Kanalı Kapandı”, TRT Haber, 27.03.2021, https://www.trthaber.com/haber/ dunya/suveys-kanali-kapandi-dunya-ticareti-buyuk-yara-aldi-568045.html (Erişim Tarihi: 24.11.2021)

${ }^{124}$ Bucsky, a.g.e., s. 151. 
heavily to expand the capacity of the canal. China also developed many commercial and diplomatic ties with Egypt in order to have more control over the canal. Besides, from these moves, China constructed its first army base abroad on Djibouti, which sits near the strait of Babel Mendeb.

The second maritime choke point on the Road is Malakka Strait. It sits between the Malay Peninsula and Sumatra Indonesia, strait is home to 40 percent of crude oil coming to South East Asia and estimated one third of China's exports going to Europe via this route. Again, China is filling near corrals on Spratly Islands to build military bases for gaining the security leverage on the straits; however, research indicates that Chinese Navy does not have enough experience and power projection capability in order to secure these critical maritime chokepoints.

An alternative to the Road is Northern Sea Route. A ship using this route could cut the distance it needs to take through the journey, which starts from China to ends in Europe. However, due to the harsh conditions of the route, passage can be used only in summers. At the same time, ice breaker fee and width of passage make route not profitable for now. However, with the global warming, the Northern Sea Route is expected to gain more traffic.

The Belt on BRI means land bridges from China to Europe and the railway transportation engages with the Belt. Regarding the railway transportation, there are several major problems as well. One of them is the width difference of the railways. China and Europe countries use same infrastructure on railways, but former Soviet countries have wider tracks. Because of that the goods needs to be transferred to suitable railway cars or the railway cars have to change their undercarriage to adapt the tracks. Either process mean losing time and efficiency.

The second major problem comes from customs. There is no common customs system between the countries, which is also a problem resulting in losing time and efficiency.

The most common method of transportation in the world is ocean transportation. 80 percent of all transportation takes place on seas. In 2018, approximately 24 million TEU have been transported via ocean transport within Eurasia. The number for railway transportation within Eurasia for the same year was $350.000 \mathrm{TEU}$. Although there is a rapid growth in demand for 
railway transportation reaching its highest point estimated 2 million TEU per year, ocean transportation has no alternative in terms of capacity.

However, rail transportation is two times faster than ocean transportation and five times cheaper than air transportation. Moreover, there is no alternative to carry such amounts of cargo from and to ports for the Central Asian countries, which has no access to international sea routes.

Using railway transportation within Eurasia bring risks and opportunities together. This research indicates that Central Asian countries will have the most benefit from railway transportation, however same countries need to invest in infrastructure substantially. Most of the freight charges are subsidized by the Chinese Goverment in order to enlarge the traffic on railways but the risk for rail transportation increases as Eurasia gets bigger with the Covid-19 outbreak.

\section{Çatışma Beyanı}

Araştırmanın yazarları olarak herhangi bir çıkar çatışması beyanımı bulunmamaktadir.

\section{Destek ve Teşekkür Beyanı}

Çalısma Doç. Dr. Fahri Erenel danısmanlğ̆ında Milli Savunma Üniversitesi Atatürk Stratejik Arasstrmalar Enstitüsü'nde savunma kaynaklar yönetimi yüksek lisans öğrencisi Baha Emir Şahin tarafindan hazrlanmıstır. Çalısmantn hazrrlanmasında emeği geçen tüm hocalarma teşekkürlerimi arz ederim.

\section{Araştırmacıların Katkı Oranı Beyanı}

Birinci yazarın çalışmaya katkı oranı \%70'dir. İkinci yazar çalışmanın danısmanı olup çalışmaya katkı oranı \%30'dur.

\section{KAYNAKÇA}

Kitaplar

KARDON Issaac, WISEMAN vd., China's Out of Area Naval Operations: Case Studies, Trajectories, Obstacles, and Potential Solutions, National Defense University Press Washington, 2010. 


\section{Makaleler}

AHMAD Riaz, MI Hong vd., "Revisiting The Potential Security Threats Linked With The China-Pakistan Economic Corridor (CPEC)", Fournal of the International Council for Small Business, 2020, Vol 1, No 1, 64-80.

ALAM Khalid Mehmood, LI Xuemei vd., "Impact of Transport Cost and Travel Time on Trade Under China-Pakistan Economic Corridor (CPEC)", Fournal of Advanced Transportation, Vol. 2019, 1-16.

AMPONSTIR Fuangfa, "Analisis Of Global Connectivity of Kra İthmus Canal Vision”, Rajapark Journal, 2020, Vol. 14, No 33, 298-307.

BUCSKY Peter, "The iron Silk Road: how important is it?", Area Development and Policy, 2020, Vol. 5, No. 2, 146-166.

CHEN Juan, "Strategic Synergy Between Egypt "Vision 2030" and China's "Belt and Road" Initiative", Outlines of Global Transformations: Politics, Economics, Law, 2018, Vol 11, No 5, 219-235.

ÇEVIK Veli Ahmet ve DURUKAN Tülin, “Çin'in Kuzey Kutbu'na Olan İlgisi: Kutup İpek Yolu”, Akdeniz İIBF Dergisi, 2020, Vol. 20, No. 2, 254-262.

GILMARTIN Heather, "The Malacca Straits as Catalyst for Multilateral Security Cooperation", Sicherheti und Frieden / Security and Peace, 2008, Vol. 26, No. 4, 220-226.

HASAN Monjur and JIAN He, "Spratly Islands Dispute in the South China Sea: Potential Solutions", Fournal of East Asia and International Law, 2019, Vol. 12, No. 1, 145-168.

MARTINEZ-ZARZOSO Inmaculada, "Alternative Sea Routes: What Effects on Maritime Trade?”, SAIS Review of International Affairs, 2013, Vol 33, No. 2, 61-74.

POPESCU Alba Lulia Catrinel, "Control of Key Maritime Straits - China's Global Strategic Objective", International Fournal of Economics and Business Administration, 2017, Vol 5, No. 1, 92-119.

TABUR İlhan Tabur, TAĞ Mehmet Nasih vd., "Korsanlık ve Deniz Haydutluğu ile Mücadele: Somali Örneği ve Türkiye'nin Katkıları”, Uluslararası İktisadi ve İdari Bilimler Dergisi, 2016, Cilt 2, Say1 1, 1-20 .

TURZI Mariano, "Latin American Silk Road: China And The Nicaragua Canal", Revista de Relaciones Internacionales, Estrategia y Seguridad, 2016, Vol. 12, No. 2, 163-178.

TUTAR Filiz Kutluay ve KOÇER Fatma Şura Bahsi, “Çin'in Yeni İpek Yolu Projesi: Bir Kuşak Bir Yol”, fournal Of Social, Humanities and Administrative Sciences, 2019, Vol. 5, No. 17, 618-626.

UYSAL Onur F., “The Iron Silk Road: How Will Turkey Be Involved?”, Caucasus International, 2016, Vol. 6, No. 1, 55-66.

QU Xiaobo and MENG Quiang, "The Economic Importance of the Straits of Malacca and Singapore: An Extreme Scenario Analysis", Transportation Research Part E Logistics and Transportation Review, 2012, Vol. 48, No. 1, 258-265.

\section{Konferans Bildirgeleri}

KUZMIN Dmitry, BAGINOV Andrei vd., "The Northern Sea Route in the conditions of the global economic environment of the transport market", Topical Problems of Architecture, Civil Engineering and Environmental Economics (TPACEE 2018) E3S Web of Conferences, 03-05 December 2018, Moskova.

SCHRAMM Hans-Joachim and ZHANG Xu, "Eurasian Rail Freight in the One Belt One Road Era”, 30. NOFOMA Conference, 13-15 June 2018, Kolding. 


\section{Raporlar}

Belt And Road Economics Opportunities and Risks of Transport Corridors, Washington: The World Bank Group, 2019.

BEUKEL Erik, "China and the South China Sea: Two Faces of Power in the Rising China's Neighborhood Policy”, Danish Institute for International Studies, Kopenhag, 2010.

CHEN Ching-mu and KUMAGAI Satoru, "Economic Impacts of the Kra Canal: An Application of the Automatic Calculation of Sea Distances by a GIS", Fapan External Trade Organization, Chiba, 2016.

DUTTON Peter A., KARDON Isaac B. Kardon vd., "China Maritime Report No. 6: Djibouti: China's First Overseas Strategic Strongpoint”, U.S Naval War College, Newport, 2020.

Eurasian Corridors: Development Potential", Paris: UIC-Freight Department, 2020.

GHIASY Richard, SU Fei vd., "The 21st Century Maritime Silk Road Security Implications and Ways Forward For The European Union”, SIPRI, Stockholm, 2018.

KENNEDY Conor M., "China Maritime Report No. 4: Civil Transport in PLA Power Projection”, U.S Naval War College, Newport, 2019.

PELTIER Chad, NURKIN Tate vd., "China's Logistics Capabilities for Expeditionary Operations", US.-China Economic and Security Review Commission, Washington, 2020. Railway Handbook 2014, IEA-UIC, Paris, 2014.

Reports On Acts Of Piracy And Armed Robbery Against Ships Annual Report - 2019, London: IMO, 2019.

Reviev Of Maritime Transport 2017, Geneva: UNCTAD, 2017.

Reviev Of Maritime Transport 2019, Geneva: UNCTAD, 2019.

Reviev Of Maritime Transport 2020, Geneva: UNCTAD, 2020.

RIFAAT Hamzah and MAINI Tridivesh Singh, "The China-Pakistan Economic Corridor Strategic Rationales, External Perspectives, and Challenges to Effective Implementation", The Stimson Center, Washington, 2016.

Silk Road Transport Corridors: Assessment of Trans-EAEU Freight Traffic Growth Potential, Eurasian Development Bank, St. Petersburg, 2018.

Suez Canal Traffic Statistics Monthly Report Fanuary 2020, Ismailia: Suez Canal Authority, 2020.

Suez Canal Traffic Statistics Annual Report 2019, Ismailia: Suez Canal Authority, 2020.

SOUTHERLAND Matthew, "China's Island Building in the South China Sea: Damage to the Marine Environment, Implications, and International Law", U.S.China Economic and Security Review Commission, Washington, 2016.

The Djiboti City - Addis Ababa Transit And Transport Corridor Turning Diagnostics Into Action, Geneva: UNCTAD, 2018.

Working Paper for Carriage Capacity of the Straits of Malacca and Singapore, Singapore: Simplus Pte. Ltd, 2009.

\section{Tezler}

MUKHTAROV Agshin, A case study: Feasibility analysis of container feeder vessel as a short sea shipping service in the Caspian Sea, Yüksek Lisans Tezi, World Maritime University, Malmö, 2018.

VAN Pham Thi Bich, ARAVOPOULOS Miltiadis, Feasibility Study on Commercial Shipping in the Northern Sea Route, Yüksek Lisans Tezi, Chalmers University of Technology, Gothenburg, 2019. 


\section{İnternet Kaynaklari}

“Afganistan Lapis Lazuli güzergahıyla Türkiye'ye bağlanacak”, Anadolu Ajansı, https://www.aa.com.tr/tr/ekonomi/afganistan-lapis-lazuli-guzergahiyla-turkiyeye-

baglanacak/1337951 (Erişim Tarihi: 29.06.2020)

"Bakü-Tiflis-Kars Demiryolu Hattında İlave 3 Bin 500 Ton Kapasite Artışı Sağlandı", TCDD, http://www.tcddtasimacilik.gov.tr/haber/447/ (Erişim Tarihi: 24.06.2020)

"Bakü-Tiflis-Kars Demir Yolu Hem Kıtaları Hem Rayları Birleştirdi", Anadolu Ajansı, https://www.aa.com.tr/tr/turkiye/baku-tiflis-kars-demir-yolu-hem-kitalari-hem-raylaribirlestirdi/1631646 (Erişim Tarihi: 24.06.2020)

"Bir Kuşak Bir Yol Projesi'nin İlk Transit Treni Avrupa'ya Uğurlandı", TCDD, http://www.tcddtasimacilik.gov.tr/haber/355/(Erişim Tarihi: 24.06.2020)

"Canal Characteristics", Suez Canal Authority, https://www.suezcanal.gov.eg/ English/About/SuezCanal/Pages/CanalCharacteristics.aspx (Erişim Tarihi: 03.07.2020)

"China Earns Ire Of Taiwan, Strengthens Ties With Genocidal Myanmar That Faces ICJ Ruling", Tamilnet, https://www.tamilnet.com/art.html?catid=79\&artid=39704 (Erişim Tarihi: 24.11.2021)

"China, Myanmar Sign Deals To Spur Belt And Road Project", Anadolu Ajans1, https://www.aa.com.tr/en/asia-pacific/china-myanmar-sign-deals-to-spur-belt-and-road-

project/1706737 (Erişim Tarihi: 25.06.2020)

"CPEC Projects Progress Update”, CPEC, http://cpec.gov.pk/progress-update (Erişim Tarihi: 04.07.2020)

"Çin, Pakistan limanı üzerinden ticaret yapmaya başladı", Anadolu Ajansı, https://www.aa.com.tr/tr/dunya/cin-pakistan-limani-uzerinden-ticaret-yapmaya-basladi/ 684844 (Erişim Tarihi: 01.07.2020)

“Demir İpekyolu'nda İlk Tren Kalkıyor", Anadolu Ajans1, https://www.aa.com.tr/ tr/ekonomi/demir-ipekyolunda-ilk-tren-kalkiyor/950718 (Erişim Tarihi: 25.06.2020)

"Demir İpek Yolu`nda 50 milyon ton yük taşınacak", Ulaştırma ve Altyapı Bakanlığı, https://www.uab.gov.tr/basin-aciklamalari/demir-ipek-yolu-nda-50-milyon-ton-yuk-

tasinacak (Erişim Tarihi: 25.06.2020)

"Demir İpek Yolu'nun İki Yıllık Serüveni”, Anadolu Ajansı, https://www.aa.com.tr/tr/ ekonomi/demir-ipek-yolunun-iki-yillik-seruveni/1627484\# (Erişim Tarihi: 24.06.2020)

"First in the new year sessions of the Working Group and General Meeting of the International Association "TITR” held in Almaty", Middle Corridor, https://middlecorridor .com/en/pressa/news/130-first-in-the-new-year-sessions-of-the-working-group-and-generalmeeting-of-the-international-association-titr-held-in-almaty (Erişim Tarihi: 27.06.2020)

"Halkalı-Kapıkule Hızlı Demiryolu Hattının Temeli Atıldı", TCDD, http://www.tcddtasimacilik.gov.tr/haber/345/ (Erişim Tarihi: 26.06.2020)

"Is The Gran Canal de Nicaragua Dead In The Water?", Today In Nicaragua, https://today nicaragua.com/is-the-gran-canal-de-nicaragua-dead-in-the-water/ (Erişim Tarihi: 27.06.2020)

"Kuşak ve Yol Girişiminin Geleceği: Çin Karakterli Bir küreselleşme mi?”, Anadolu Ajansı, https://www.aa.com.tr/tr/analiz/kusak-ve-yol-girisiminin-gelecegi-cin-karakterli-birkuresellesme-mi/2083696 (Erişim Tarihi:23.12.2020)

"Marmaray'dan Geçen İlk Yurt İçi Treni Tekirdağ’a Ulaştı", Anadolu Ajansı, https://www.aa.com.tr/tr/turkiye/marmaraydan-gecen-ilk-yurt-ici-treni-tekirdaga-

ulasti/1834758 (Erişim Tarihi: 27.06.2020) 
"Melting Arctic ice clears the way for supertanker voyages", The Guardian, 5.10.2011 https://www.theguardian.com/environment/2011/oct/05/melting-arctic-ice-supertankers (Erişim Tarihi: 23.11.2021)

"News Review of the Events on the NSR \#1 May 2020", Centre for High North Logistics, https://arctic-lio.com/news-review-of-the-events-on-the-nsrl-may-2020/ (Erişim Tarihi: 28.06.2020)

"NSR Shipping Traffic - Transits 2018", Centre for High North Logistics, https://arcticlio.com/nsr-shipping-traffic-transits-2018/ (Erişim Tarihi: 28.06.2020)

"Open Source Backgrounder: Dijbouti, Foreign Military Bases on the Horn of Africa-Who is There? What are They Up To?", Small Wars Journal, https://smallwarsjournal.com/ jrnl/art/open-source-backgrounder-djibouti-foreign-military-bases-horn-africa-who-therewhat-are (Erişim Tarihi: 29.06.2020)

"Port of Baku: everything comes together in Alat", Railfreight, https://www.railfreight.com/belt androad/2019/10/29/port-of-baku-everything-comes-together-in-alyat/(Erişim Tarihi: 27.06.2020)

"President Xi Jinping Delivers Important Speech and Proposes to Build a Silk Road Economic Belt with Central Asian Countries”, Ministary of Foreign Affairs of The People's Republic of China, https://www.fmprc.gov.cn/mfa_eng/topics_665678/xipfwzysiesgitfhshzz fh_665686/t1076334.shtml (Erişim Tarihi: 01.17.2020)

"Suez Canal Makes All-Time Traffic Record", Xinhuanews, http://www.xinhuanet. com/english/2019-08/02/c_138279360.htm (Erişim Tarihi: 02.07.2020)

"Süveyş Kanalı Kapandi”, TRT Haber, https://www.trthaber.com/haber/dunya/suveyskanali-kapandi-dunya-ticareti-buyuk-yara-aldi-568045.html (Erişim Tarihi: 24.11.2021)

"Time to revisit canal Project", Bangkok Post, https://www.bangkokpost.com/ opinion/opinion/1839359/time-to-revisit-canal-project (Erişim Tarihi: 28.06.2020)

"Türkiye ile Gürcistan Arasında Bir İlk Yarın Sefere Çıkıyor”, Yenişafak, https://www.yenisafak.com/ekonomi/turkiye-ile-gurcistan-arasindaki-ilk-ihracat-treniyarin-hareket-edecek-3499347 (Erişim Tarihi: 24.11.2021).

“Türkiye Çin'e 'İhracat Treni' Gönderecek”, Anadolu Ajansı, https://www.aa.com.tr/tr/ turkiye/turkiye-cine-ihracat-treni-gonderecek/1680753 (Erişim Tarihi: 25.06.2020)

"VENTA MAERSK", Marine Traffic, https://www.marinetraffic.com/en/ais/details/ships/shipid :5568438/mmsi:219115000/imo:9775763/vessel:VENTA_MAERSK(Erişim Tarihi: 27.06.2020)

"Yeni Bir Rekor Kıran İhraç Treni Yola Çıktı", TCDD, http://www.tcddtasimacilik.gov.tr/ haber/440/ (Erişim Tarihi: 26.06.2020)

“Yeni Dünya Düzeni'nin Kuruluş Projesi”, 21. Yüzyıl Türkiye Enstitüsü, https://www.21yyte.org/tr/merkezler/bolgesel-arastirma-merkezleri/asya-pasifik-arastirma lari-merkezi/yeni-dunya-duzeninin-kurulus-projesi-kusak-ve-yol-girisimi-yeni-i-pek-yolu (Erişim Tarihi: 23.12.2020)

"Yurtdışı Yük Taşımacılığı", TCDD, http://www.tcddtasimacilik.gov.tr/sayfa/yurtdisi-yuktasimaciligi/ (Erişim Tarihi: 23.06.2020)

"Why the US Navy Sails Past Disputed Artificial Islands Claimed by China", ABC News, https://abcnews.go.com/Politics/us-navy-sails-past-disputed-artificial-islands-

claimed/story?id=60993256 (Erişim Tarihi: 23.11 .2021 )

"World's largest containership makes its first crossing through Suez Canal", Offshore Energy, https://www.offshore-energy.biz/worlds-largest-containership-makes-its-firstcrossing-through-suez-canal/ (Erişim Tarihi: 24.11.2021) 